\title{
THE ENFORCEMENT OF CHILD CUSTODY ORDERS BY CONTEMPT REMEDIES
}

\author{
Margaret M. Mahoney ${ }^{*}$
}

Table of Contents

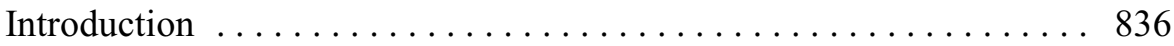

Part I: The Nature of Parenting Plan Orders . . . . . . . . . . . . . 838

A. Custody Orders Protect Parent-Child Relationships . . . . . 838

B. The Residential and Decisionmaking Provisions of Custody Orders . . . . . . . . . . . . . . . . . . . . 839

C. The Coercive Nature of Custody Orders . . . . . . . . . . 841

D. Custody Law in Historical Context . . . . . . . . . . . . 843

E. Custody Orders Are Not Premised on a Determination of

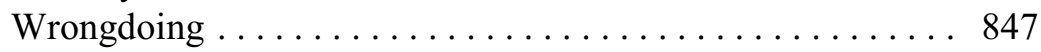

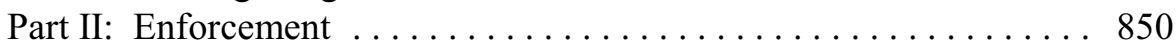

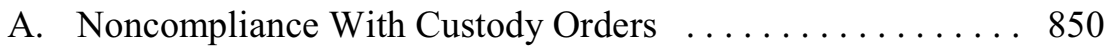

B. The Public and Private Interests at Stake $\ldots \ldots \ldots \ldots . \ldots 852$

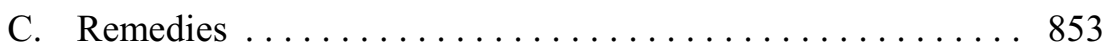

D. Judicial Discretion in Contempt Cases ........... 858

E. The Distinction Between Civil and Criminal Contempt .... 861

F. Coercive Civil Contempt Remedies in Child Custody Cases .............................. 866

G. Compensatory Civil Contempt Remedies in Child Custody Cases . . . . . . . . . . . . . . . . . . . . . . 871

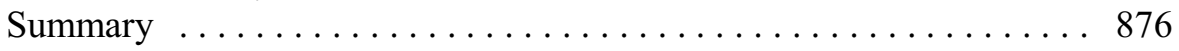

* Professor of Law, University of Pittsburgh. I would like to thank my University of Pittsburgh colleagues David Herring and Rhonda Wasserman for their thoughtful comments on an earlier draft of this Article, law students Vincent Mersich and Katherine Voye for their research assistance, and members of the Document Technology Center for their technical assistance. 


\section{INTRODUCTION}

Millions of divorced couples are regulated in their conduct as parents by the terms of parenting plans or custody and visitation orders established by the divorce courts. These judicial orders restrict certain parental choices, such as the amount of time that each parent will spend with the children and the manner in which important child-related decisions will be made. Prior to divorce, these same families were free of such detailed regulation by the state. In the eyes of the law, the post-divorce regulation of parenting activity serves the important purpose of protecting, in an orderly fashion, established relationships between children and both of their parents in light of the changed family circumstances that result from divorce.

Judicial orders allocating parental rights and responsibilities following divorce are mandatory in nature, requiring both parents to engage in certain types of conduct and to refrain from others. For example, a parent may be required to deliver the children to the physical custody of the other parent at specified times and in a specified manner. In another familiar example, one parent may be required to refrain from interfering in the children's medical care or education, if these areas of legal custody have been assigned to the other parent.

Although the terminology of "injunctive court orders" is not often used in the field of child custody law, the child-related orders of the divorce court are, indeed, injunctive in nature. They are typical of the judicial orders historically entered by the courts acting in equity, directing one party in a lawsuit to act in a specified way in order to vindicate the legal rights of the other party. Furthermore, in the event of noncompliance by the party directed to act, custody orders are enforceable by the remedies generally associated with "equitable," "injunctive," or "coercive" court orders. Most notably, a parent who fails to comply with the terms of a court-ordered parenting plan is subject to the remedies of civil and criminal contempt, which may result in the imposition of a fine or jail sentence by the court.

This Article evaluates the nature of custody and visitation orders as coercive court orders, and their enforcement via civil and criminal contempt remedies. Studied against the backdrop of the law of injunctions, certain aspects of custody law illustrate nicely the general features of injunctive remedies doctrine. For example, the substantive and procedural confusion involved in distinguishing between civil and criminal contempt, which plagues the enforcement of injunctive orders in other fields such as torts and contracts, routinely complicates the enforcement of court-ordered parenting plans. Other 
examples of commonality involve the operation of both private interests and public interests (the vindication of judicial authority), and the scope of judicial discretion.

Other dominant features of custody orders and their enforcement, however, are not consistent with the general definition and operation of injunctive remedies. First, injunctive or coercive court orders typically operate as a remedy for past unlawful activity. In a familiar example, the party to a contract may be ordered to specifically perform contract duties, only after the court determines that a past breach of the contract has occurred. By way of contrast, in the divorce context, the court enters coercive parenting orders absent any determination that either parent has engaged in past unlawful conduct. Both the order of specific performance in the contract case and the custody order in the divorce case become enforceable by contempt, in the event of subsequent noncompliance.

A second aspect of custody orders also sets them apart from the general model of the injunctive or coercive court order. Namely, in many other fields, the courts have discretion in deciding whether to impose injunctive relief or another form of relief (often monetary damages). Several factors influence the selection of remedy; for example, injunctions are less likely to be entered if the court anticipates a long or difficult period of judicial supervision over the party enjoined. By way of contrast, the divorce courts are required, with rare exception, to enter custody orders designed to regulate the conduct of parents over a period of years, even in cases where parental conflict in the past suggests that compliance problems may arise in the future.

Like the routine entry of coercive custody orders absent prior wrongdoing, this additional variation from the dominant model of the injunction reflects the compelling nature of the family interests regulated in the post-divorce custody and visitation context.

Part I of this Article explores the nature of custody and visitation orders as coercive judicial orders mandating specified post-divorce conduct by parents. The discussion explores the history of custody jurisdiction in the equity courts prior to the merger of law and equity, and the continuing characterization of custody law as a field where the courts exert direct authority over individuals. This Part also discusses the aspects of custody orders that are distinct from other injunctive or coercive orders, and the significance of these differences.

Part II focuses on the enforcement of court-ordered parenting plans, especially via the remedies of civil and criminal contempt. A close analysis of selected custody contempt cases reveals the ways in which classic contempt remedies have been applied and sometimes reshaped to fit the special 
enforcement requirements in this field. The flexible formulation of contempt sanctions in these enforcement cases, like the ready availability of coercive orders at the time of divorce, involves significant adjustments to traditional remedies doctrines.

The law of injunctions and contempt remedies are key features of custody and visitation law. As described in this Article, traditional doctrines governing the entry and enforcement of coercive judicial orders have been adjusted in significant ways in order to address the public and private interests involved in the post-divorce family.

\section{Part I: The Nature of Parenting Plan Orders}

\section{A. Custody Orders Protect Parent-Child Relationships}

In the eyes of the law, the relationships established between parents and their minor children are a key element in the maintenance of successful families and communities, entitled to legal recognition and protection. Various legal doctrines reflect the view that children's interests are wellserved by the maintenance of strong ties to the parents who provide support and guidance to them. ${ }^{1}$ Furthermore, the parent's interest in this important relationship has been characterized by the Supreme Court as a fundamental right in the constitutional sense. ${ }^{2}$

The state's support for parent-child relationships and the constitutional importance assigned to parenting do not lose their force in the event of divorce between married parents. ${ }^{3}$ In these circumstances, the divorce courts are authorized by state law to issue orders for the purpose of protecting

1. See Scott E. Friedman, The Law of Parent-Child Relationships ch. 5 (1992) (describing parental responsibility for the financial support, education, and medical care of children); $i d$. ch. 6 (describing parental authority to discipline children); id. ch. 9[I] (describing tort doctrines that protect the parent-child relationship).

2. See Troxel v. Granville, 530 U.S. 57 (2000) (discussing constitutional protection for parental rights in the context of grandparent visitation); JoHn E. NowAK \& RONALD D. RotUnDA, ConstiTUTIONAL LAW $\S 13.4$, at 612 (7th ed. 2004) (discussing protection for parents under the Due Process Clause in settings where the state seeks to involuntarily terminate parental rights).

3. See, e.g., Me. Rev. Stat. AnN. tit. 19-A, § 1653(1)(C) (Supp. 2004) ("The Legislature finds and declares that it is the public policy of this State to assure minor children of frequent and continuing contact with both parents after the parents have separated or dissolved their marriage . . . ."); AMERICAN Law Institute, Principles of the Law of Family Dissolution: Analysis and Recommendations $\S 2.02 \mathrm{cmts}$. b, e (2002) [hereinafter ALIPRINCIPLES] (describing "child's best interests," "[f]airness to the parents," and "[c]ontinuity of existing parent-child attachments" as the primary goals of regulation at the time of divorce). 
established family relationships. In the context of divorce, where children have resided with both of their parents in the past, a strong presumption exists that the court's orders will recognize and protect the children's future relationships with both parents. Thus, "[c]ourts have recognized authorities that say the child has a right to know, love, and respect both parents and to receive guidance and love from both. . . . If both parents are fit, usually a child's best interests are served through continuing contact with both parents." ${ }^{4}$ This result in the post-divorce family also protects the relational interests of parents vis-à-vis their children. ${ }^{5}$

The terms of a post-divorce custody arrangement or parenting plan may be set by the parents themselves, subject to court approval. ${ }^{6}$ Many divorcing couples take advantage of this settlement option. ${ }^{7}$ Absent such an agreement between the parents, the divorce court sets the terms, by reference to general standards established by state law. ${ }^{8}$ In either case, the court ultimately issues orders describing a parenting plan designed to serve the interests of the children following their parents' divorce.

\section{B. The Residential and Decisionmaking Provisions of Custody Orders}

Court-ordered parenting plans must address two key issues. First, the physical or residential custody part of the order must state where the children

4. 3 Arnold H. Rutkin, Family Law and Practice $\$ 32.09$ [1], at 32-263 (2006). See also ALI PrincIPles, supra note $3, \S 2.11$ (describing circumstances in which courts may deny post-divorce custodial responsibility to a parent).

5. See, e.g., Kan. Stat. Ann. § 60-1616(a) (Supp. 2005) (“A parent is entitled to reasonable parenting time unless the court finds, after a hearing, that the exercise of parenting time would seriously endanger the child's physical, mental, moral or emotional health.") (emphasis added); JoHN DE WiTT Gregory et AL., Understanding Family LaW § 11.05[A] (3d ed. 2005); 3 RutKin, supra note 4, $\S 32.09[2]$.

6. See Martin Guggenheim, What's Wrong With Children's Rights 154 (2005) (“Although, technically, courts have the residual power to disapprove divorce-related agreements, private settlements are routinely approved by the courts in uncontested divorces."); ALI PRINCIPLES, supra note 3, ch. 1, at 5 ("Although a high percentage of custody arrangements are settled by agreement of the parents, under most states' laws a court must review an agreement to determine whether it is in the child's best interests. . . . Despite the appearance of review, however, independent judicial inquiry is difficult because of the inaccessibility of facts that might dictate a different result.") (citations omitted).

7. See Robert H. Mnookin, Child-Custody Adjudication: Judicial Functions in the Face of Indeterminacy, 39 L. \& Contemp. Probs., Summer 1975, at 226, 267 n. 189.

8. See, e.g., W. VA. Code ANN. §§ 48-9-206(a), -207(a) (LexisNexis 2004) (establishing the standards to be employed by the court in setting custody terms " $[\mathrm{u}]$ nless otherwise resolved by agreement of the parents"); ALI Principles, supra note 3, ch. 1, at 6 ("When the parents do not agree on a joint [parenting] plan, the court must formulate one, applying the criteria set forth in the [ALI provisions establishing standards for allocating custodial responsibilities]."). 
will reside, and the periods of time they will spend with each parent. ${ }^{9}$ And second, the legal custody or decision making part of the order must detail the authority of one or both parents over important areas of future decision making, such as medical care and education, for the children. ${ }^{10}$

Decision making authority as to particular topics affecting children in the future can be assigned to one parent or to both simultaneously. The term "joint legal custody" typically contemplates shared decision making authority by the parents regarding some or all areas of future care for the children. ${ }^{11}$

While divorced parents can share authority in this manner for future decisions regarding the children, they generally cannot share the same periods of physical custody. Various models exist for the allocation of physical custody, ${ }^{12}$ and a divorce decree typically spells out the time to be spent by the children with each parent. In cases where one parent is assigned the responsibility of serving as the primary residential custodian, so-called "visitation orders" of the court establish the times of access for the other parent."

The West Virginia statutes governing post-divorce parenting arrangements reflect the features described above: the ability of parents to formulate their own plan, the need to address both residential and decision making issues for the children, and the court's role in protecting the interests of the children. Thus, a provision titled "Allocation of significant decisionmaking responsibility" states that "[u]nless otherwise resolved by agreement

9. Homer H. Clark, JR., The Law of Domestic Relations in the United States $§ 19.2$, at 790 (2d ed. 1988); 2 Sandra Morgan Little, Child Custody and Visitation Law and Practice $\S 10.03[3][\mathrm{b}]$, at $10-23$ (2006).

10. ClarK, supra note 9, § 19.2, at 789-90; 2 LitTLE, supra note 9, § 10.03[3][b], at 10-21.

11. See generally GugGenheim, supra note 6 , at 148-50 (summarizing the evolving role of joint custody provisions in state custody laws in recent decades).

12. See Marygold S. Melli, The American Law Institute Principles of Family Dissolution, the Approximation Rule and Shared-Parenting, 25 N. ILL. U. L. REV. 347, 351-56 (2005).

13. Critics point out that the traditional terms "custody" and "visitation" tend to limit the ways in which post-divorce parenting can be conceptualized. The drafters of the Principles of the Law of Family Dissolution expressed this concern and proposed alternative terminology, as follows:

These traditional terms represent, and help to perpetuate, an adversarial, win-lose paradigm of divorce. ... [The ALI] uses "custodial responsibility" to encompass all forms of custody and visitation. The more inclusive terminology expresses the ordinary expectation that both parents have meaningful responsibilities for their child at divorce; it leaves open the question of what those responsibilities will be.

ALI PRINCIPLES, supra note 3, ch. 1, at 7. Another alternative to the traditional terminology of "custody" and "visitation" employs the general label "parenting plan" to cover the court-defined rights and duties of parents. The legislatures in certain states have rewritten their statutes in response to criticism of the traditional terminology in this field. See, e.g., Kan. Stat. AnN. § 60-1616(a) (Supp. 2005). The majority of state statutes continue to use the terms "custody" and "visitation." 
of the parents ...., the court shall allocate responsibility for making significant life decisions on behalf of the child, including the child's education and health care, to one parent or to two parents jointly, in accordance with the child's best interest ...." "14 An additional provision addresses the "[a]llocation of custodial responsibility" as follows: "Unless otherwise resolved by agreement of the parents ... or unless manifestly harmful to the child, the court shall allocate custodial responsibility so that the proportion of custodial time the child spends with each parent approximates the proportion of time each parent spent performing caretaking functions for the child prior to the parents' separation ...."15

\section{The Coercive Nature of Custody Orders}

Court orders relating to the residential and decision making aspects of post-divorce parenting are coercive in nature, designed to govern the conduct of family members for the period of years between the parents' divorce and the children's ages of majority. Residential and legal custody orders require the parents to act or not act in certain ways.

The residential terms of a typical custody order describe when the children will spend time with each parent, and how the periodic transfer of physical custody will be accomplished. Each parent has affirmative duties, then, to release the children into the care of the other at the times and in the manner described in the custody order.

For example, if the parenting plan provides that children will reside with their mother during the week and their father on weekends, the mother would be in noncompliance if, without obtaining a prior modification of the plan, she took the children on vacation for a full week and failed to return them to the father for the weekend. Conversely, the father's conduct would be unlawful

14. W. VA. Code AnN. § 48-9-207(a) (LexisNexis 2004).

15. Id. § 48-9-206(a). Notably, the West Virginia legislation sets out two different standards to govern judicial decision making about the dual aspects of custody. Thus, the provision regarding legal custody establishes the best interests of the child standard, which is the standard most frequently employed in custody cases nationwide. Under this standard, the court has wide discretion in deciding which facts and circumstances in each case are most important in formulating a custody order. By way of contrast, the approximation standard established in the West Virginia residential custody provision leaves less discretion to the judge, because information about the role of each parent as caregiver prior to divorce must be given the greatest weight. This enactment follows the model proposed in the American Law Institute's Principles of the Law of Family Dissolution, see ALI PRINCIPLES, supra note 3, § 2.08, and does not represent the majority rule in the United States. Many state custody laws employ a less directive standard, often requiring the judge to allocate physical as well as legal custody according to the discretionary best interests of the child standard. See Gregory et AL., supra note 5, § 11.03[A]. 
if he failed to return the children to the care of their mother at the end of a weekend period. Each of these scenarios involves a failure by the noncompliant parent to take affirmative actions required by the initial custody order.

The legal or decision making aspects of a parenting plan similarly create mandates regarding post-divorce parenting conduct. Often these orders require one parent to refrain from taking certain actions with respect to the children. When sole legal custody is assigned by the court to one parent, an enforceable obligation is imposed upon the other not to interfere with the custodian's authority. ${ }^{16}$ For example, if the parent with sole authority regarding medical care decides against a child's elective tonsillectomy, the other parent is obligated to abide by this decision, even if he or she believes that the procedure would be beneficial. If the noncustodial parent takes the child to a hospital for the surgery during a period of scheduled visitation, he or she would be in noncompliance with the custody order.

Divorce decrees may seek to govern additional aspects of post-divorce parenting, beyond the major aspects of residential and decision making custody. Additional regulations may be included because they appear in a parenting plan agreement, or because the divorce court believes that they would serve the children's interests. One category of regulations involves conduct of the parents that would take place in the presence of the children ranging from smoking cigarettes ${ }^{17}$ to spending time with a new romantic partner. ${ }^{18}$ A second category of court orders requires cooperative or respectful behavior between the parents. For example, the custody order in the case of Ryder v. Ryder ${ }^{19}$ included the following provisions:

The parties shall cooperate with each other and communicate with each other in regards to their minor child ... . The parties shall attempt to resolve their differences without

16. See, e.g., Funk v. Macaulay, 457 N.E.2d 223, 229 (Ind. Ct. App. 1983) (upholding trial court contempt judgment based on a general finding that "the defendant . . is interfering with and interrupting the care, custody, and guidance of the plaintiff with respect to the minor children[,]" and the more specific finding "that the defendant has counseled and encouraged [the] minor child of the parties not to attend school and that such conduct has interfered and prevented the plaintiff from requiring said minor child to attend school").

17. See Jeffrey L. Hall, Secondhand Smoke as an Issue in Child Custody/Visitation Disputes, 97 W. VA. L. REV. 115 (1994).

18. The parent who spends less residential time with the children is more likely to find himself or herself subject to restrictions of this nature. See GrEgORY ET AL., supra note 5, § 11.05[B] (discussing "restrictions on visitation").

19. Ryder v. Ryder, No. 2001CA00190, 2002 WL 258218 (Ohio Ct. App. Feb. 19, 2002). 
unnecessary court involvement, and each shall make an effort to be flexible when able for the sake, benefit and best interests of the minor child $\ldots{ }^{20}$

All of these custody provisions are enforceable by the court. If one parent believes that the other parent has violated the residential, decision making or other provisions of their post-divorce parenting plan, he or she may initiate an enforcement proceeding. The court then will hold a hearing to determine whether the other parent in fact violated the earlier court orders and, if so, the appropriate remedy. In the Ryder case, for example, the mother was held in contempt of court for violating the custody order requiring the parents to "communicate with each other." 11

The regulation of post-divorce parenting conduct in this fashion can be experienced by parents as a serious interference with their autonomy. This intrusion by the state, in the form of enforceable judicial mandates about future conduct, is intended to accomplish the goal of supporting the relationships between children and both of their parents following divorce.

\section{Custody Law in Historical Context}

The historical background of child custody law sheds light on the coercive nature of parenting plan and child custody and visitation orders in the modern family law context. The law of child custody is a survivor of the equity system of jurisprudence, which first arose in the Chancellor's court in England and developed over the centuries alongside the courts of law in England and the United States. ${ }^{22}$ Professor Homer Clark traced the power of courts in equity to act for the welfare of children back to the seventeenth century, and attributed the equitable character of such actions "to the range and flexibility of remedy available in equity. ${ }^{23}$

20. Id. at *1.

21. Id. at *1-2 (noting that the trial court's finding about mother's failure to communicate with father was based upon his "testi[mony] that he was never notified that [the mother] was not going to allow [the son] to come ... for the December visit and he ... waited for them to arrive at the scheduled time").

22. Within this dual system, different rules governed the subject matter, procedure, and enforcement of court orders in law and in equity. See Lawrence M. Friedman, A History of American Law 26-27 (2d ed. 1985) (describing the evolution of law and equity systems in England, and their adoption in the United States).

23. ClARK, supra note $9, \S 19.1$, at 786 . For an extensive treatment of the historical development of custody law in England, see Danaya C. Wright, The Crisis of Child Custody: A History of the Birth of Family Law in England, 11 Colum. J. Gender \& L. 175 (2002) [hereinafter Wright, The Crisis]. According to Professor Wright, the law courts and the Chancellor initially shared jurisdiction in matters involving the custody of children. Then, "[b]y the mid-eighteenth century the justices of the [law courts] 
Generally speaking, in the era described by Professor Clark, the courts of law adjudicated specific rights and liabilities of litigating parties, and their orders were enforceable in a subsequent action by the prevailing party against the money or property of the other. ${ }^{24}$ By way of contrast, judgments made by courts in equity about the litigants' respective rights typically resulted in an order requiring the losing party to perform a specified act. The judicial enforcement of such equitable orders focused on the person of the defendant, rather than his or her property. ${ }^{25}$ A key enforcement device in equity was the contempt power of the court directed against the individual who defied the court's initial order, for which the sanctions of a monetary fine and imprisonment could be imposed. Professor Dan Dobbs highlighted the crucial differences between the two systems of justice, as follows:

In the old separate court system, law courts adjudicated rights and liabilities but they issued no commands. Instead they preferred to enforce judgments in rem. The old separate equity courts worked the other way around. Their decrees ended in a personal command telling the defendant to do something or to cease doing something. . . This difference wrought a difference in enforcement. The old separate equity court often enforced its decree by using contempt powers, fining or imprisoning the defendant until he complied with the decree. This is sometimes called in personam enforcement, in contrast to the in rem enforcement at law. ${ }^{26}$

Within this historical framework, court orders regarding the future parenting of children constituted the quintessential "equitable order." A custody or visitation order was a "personal directive" in the sense described by Professor Dobbs, requiring parents to act (or not act) in certain ways with regard to matters affecting their children.

In the evolution of the legal systems in England and the United States, the separate courts of law and equity ultimately merged into a single unified judicial system. ${ }^{27}$ In spite of this structural unification, judges and analysts of the law continue to this day to distinguish between judicial orders that

uniformly attributed to the Chancellor the jurisdiction to oversee matters regarding infants by delegation of the crown's parens patriae powers." Id. at 189. Notably, the first reported interspousal custody case did not appear until 1804. See Danaya C. Wright, De Manneville v. De Manneville: Rethinking the Birth of Custody Law under Patriarchy, 17 LAw \& Hist. Rev. 247 (1999). Earlier cases typically involved the child's father and a nonparent as parties. See Wright, The Crisis, supra, at 182-88. In 1857, Parliament created a unified family court in England with jurisdiction over the issues arising in divorce cases, including custody. Id. at 178 .

24. Dan B. Dobbs, The Law of Remedies $\S 1.1$, at 5 (2d ed. abridged 1993).

25. $I d$.

26. Id. $\S 1.4$, at 13 .

27. See id. $\S 1.2$. 
adjudicate rights with an eye toward satisfaction in the form of money, and orders that mandate personal behavior. One meaningful consequence flowing from this continuing distinction involves the different remedies available to enforce each type of court order. Remedial orders of the court directed against the noncompliant party, such as contempt, remain the hallmark of enforcement as to orders that would have been characterized in the past as equitable. Professor Dobbs has summarized these aspects of the modern legal system following merger of the separate systems of law and equity, as follows:

Most judicial systems have long since combined law and equity courts in a single court having the powers of both the old law and the old equity courts. So it is technically no longer right ... to say that equity enforces decrees in personam while law enforces them in rem. However, the kind of decree equity once issued, a coercive, in personam order directing the defendant to act in a specified way, is enforceable by contempt just as it was when there were separate equity courts. It is still common, by way of shorthand, to associate contempt powers with "equity," although it is more accurate to associate them with a valid coercive order. ${ }^{28}$

Within this modern frame of reference, custody and visitation orders are readily characterized as "coercive" orders. Although divorce court orders regarding the future parenting of children are not generally referred to as "injunctions," they fall squarely into the general definition of injunctive court orders that are enforceable, inter alia, by contempt. ${ }^{29}$

The historical assignment of custody cases to the courts of equity supports the routine entry of coercive custody orders in the modern context. In formulating remedies in individual cases, modern courts sometimes apply a doctrine called the "irreparable harm rule," ${ }^{30}$ which creates a preference for legal remedies, typically money damages, and restricts the availability of injunctive relief. ${ }^{31}$ An important consideration under this choice-of-remedies doctrine is the predictability of compliance with and need for extensive judicial supervision over an injunctive order. ${ }^{32}$ Notably, the limitation on

28. Id. $\S 1.4$, at 13 (emphasis added) (using a custody hypothetical to illustrate the point).

29. See generally JAMES M. Fischer, Underst ANDing Remedies § 2[d], at 5 (1999) ("Injunctions are a form of equitable relief whereby a defendant is ordered to do something (mandatory injunction) or refrain from doing something (prohibitory or negative injunction). A defendant who violates the terms of an injunction may be sanctioned by being held in contempt of court.").

30. See DobBs, supra note 24, § 2.5(1). But see id. § 1.1, at 6 (describing modern trend toward diluting the "irreparable harm rule").

31. The rule restricts injunctive relief to situations where legal remedies would be inadequate to compensate the injured party. See Fischer, supra note 29, § 21[a], at 148-49.

32. See id. $\S 24$, at $168-69$ (noting that "equitable injunctive relief has been refused when the required performance would be unreasonably difficult to enforce or require lengthy judicial supervision"); 
coercive or injunctive orders under the irreparable harm rule does not apply to "those matters that had historically and traditionally been heard in equity,",33 a category that includes child custody cases.

Indeed, no traditionally "legal" or "in rem" order of the court, such as an order to pay money, could address the goal of protecting post-divorce parentchild relationships. Coercive orders, designed to regulate the future conduct of both parents and enforceable by the remedy of contempt, are the norm in child custody cases. Considerations involving the difficulty of future enforcement, which influence the decision whether to enter coercive orders under the irreparable harm doctrine, have no application in this context. ${ }^{34}$ Neither demonstrated animosities within the family, which may suggest compliance problems in the future, nor the ages of the children, which indicate the likely duration of the court's order, acts as a deterrent. Coercive orders that endure until children reach adulthood are the norm. The door, then, is opened at the time of divorce to the possibility of ongoing judicial involvement for extended periods of time, even in difficult cases. The doctrines relating to enforcement and remedies, discussed in Part II, take on added significance in these circumstances. ${ }^{35}$

Doвbs, supra note $24, \S 2.5(4)$, at 99 ("The availability of equitable remedies is . . limited by considerations of practicality and convenience [but] [t] he stronger the need for coercive relief, the more willing the chancellor to grant the relief in spite of fearful anticipations."); EDWARD YORIO, CONTRACT Enforcement: Specific Performance and Injunctions § 3.3.2, at 58-59 (1989 \& Supp. 2001) (discussing the length of time required for completion as a factor in judicial decisions whether to order specific enforcement of a contract).

33. FISCHER, supra note $29, \S 21$ [a], at 148 (listing "matters involving fiduciaries, . . f fraud, mistake, and bankruptcy, to name but a few" as examples of such equitable matters). See also DobBs, supra note $24, \S 2.5(1)$, at 89 .

34. Although the potential for enforcement difficulties does not deter courts from entering coercive custody and visitation orders, the likelihood of enforcement problems may influence the terms of those orders in individual cases. See 3 RutKIN, supra note 4, §32.09[4][a] ("In a few states, statutes allow the court to consider in the initial custody decision which parent is likely to allow frequent and continuing contact with the other parent."); GREGORY ET AL., supra note 5, § 11.04[C] (describing judicial consideration of the likelihood of parental cooperation and compliance, in decisions whether to establish joint custody orders).

35. Institutional reform cases provide another setting where coercive judicial orders often involve the courts with the parties and the subject matter of the decree for an extended period of time. The "structural injunction" is a remedy utilized in cases where a public institution has conducted its business in an unconstitutional manner, such as a school district that has failed to comply with desegregation requirements. See Fischer, supra note 29, § 46(c); Owen M. Fiss, The Civil Rights Injunction 92-94 (1978). The injunction typically requires reorganization of the public institution to bring its operation into constitutional compliance, a process that may take many years to complete. See James M. Hirschhorn, Where the Money Is: Remedies to Finance Compliance with Strict Structural Injunctions, 82 Mich. L. REv. 1815, 1816 (1984) (describing "the formal powers that are available to the federal courts" in cases where institutional defendants assert an inability to comply with structural injunctions due to lack of 


\section{E. Custody Orders Are Not Premised on a Determination of Wrongdoing}

An element of necessity characterizes the entry of coercive judicial orders regarding the custody of children at the time of divorce. State custody laws reflect the view that such orders are necessary to protect existing parent-child relationships, in a clear and certain manner, in light of the family's changed circumstances. ${ }^{36}$ This context for creating coercive judicial orders differs in one significant aspect from the entry of coercive or injunctive orders in other litigation settings. Namely, in many other types of cases, such as tort and contract cases, the coercive or injunctive order functions as a remedy for one party based on a judicial determination of wrongdoing by the other. No such determination of wrongdoing by one party takes place when the court initially establishes the coercive terms of a post-divorce parenting plan.

A description of typical injunctive orders in the fields of torts and contracts serves to illustrate the difference. In a tort case where the plaintiff complains that a structure built by the defendant unlawfully encroaches on the plaintiff's land, the court must first determine whether a trespass has in fact occurred. If so, the available remedies include damages or a coercive, injunctive order requiring the defendant to remove the encroaching structure. In the event that injunctive relief is granted, and the defendant subsequently fails to comply, the plaintiff then may bring an action for contempt against the defendant. ${ }^{37}$ Another familiar example arises in the context of contract enforcement. Here, the court may order the defendant to perform obligations arising under a private contract, based on a threshold determination of the defendant's past unlawful failure to perform them. If the defendant subsequently fails to comply with the order of specific performance, the plaintiff may initiate an enforcement proceeding in which the defendant may be held in contempt of court. ${ }^{38}$

By way of contrast, entry of the initial custody order in a divorce proceeding involves no determination of wrongdoing by either parent. The custody orders of the divorce court are coercive, injunctive orders, like the

financial resources); Brian K. Landsberg, The Desegregated School System and the Retrogression Plan, 48 LA. L. REv. 789 (1988) (tracing the history of litigation involving the public schools in Norfolk, Virginia).

36. See generally 2 LitTLE, supra note $9, \S 10.03$ [2], at 10-20 ("As long as there is no court directive in effect, both parents continue to have equal rights in the child.").

37. See Fischer, supra note $29, \S 314$ [a], at 732-33 (discussing the trespass hypothetical).

38. See Yorio, supra note $32, \S 1.2 .2$, at 7-9. 
injunction in a trespass case or the order to specifically perform contractual obligations in a breach of contract case. Furthermore, the failure by one parent to comply with the terms of a court-ordered parenting plan entitles the other parent to seek the same type of judicial enforcement, including contempt remedies, available in the tort and contract examples. The distinction highlighted here is the absence of any unlawful conduct by one party, such as the commission of a tort or breach of a contract, underlying the entry of the initial custody order. ${ }^{39}$

Professor Clark addressed this aspect of initial custody and visitation orders, involving the absence of any claim or finding of wrongdoing, when he observed that "[i]n its practical consequences [the custody proceeding in equity] is much like a declaratory judgment suit ...."40 That is, the function of the custody order is to articulate the respective rights and responsibilities of the parents under a post-divorce parenting plan. This characterization as a "declaratory judgment," however, fails to capture the coercive aspect of the typical custody order. As a general rule, the declaratory judgment "does not compel an immediate, specific obligation to do something. Such judgments lack an 'operative command." ",41

While the court-ordered parenting plan could be viewed as a mere declaration of the respective rights and responsibilities of the parents regarding the future residence of and decision making for their minor children, divorce courts typically intend to do more. That is, they intend to set the family plan in motion by mandating certain conduct of the parties.

Indeed, the custody statutes in several states require divorce courts to clearly state that the terms of their orders are mandatory. For example, the Rhode Island statute provides that " $[\mathrm{t}]$ he court shall mandate compliance with its order .... In the event of noncompliance, the [aggrieved person] may file a motion for contempt ...."42

In the absence of such express guidance, parents have sometimes questioned whether custody and visitation orders are, in fact, mandates regarding future conduct. For example, an order in the case of MacIntosh $v$.

39. Even in a fault divorce system, filing for divorce or establishing fault grounds for ending a marriage can not be regarded as the establishment of wrongdoing in this sense.

40. ClARK, supra note $9, \S 19.3$, at 794 .

41. FISCHER, supra note $29, \S 2(\mathrm{f})$, at 6 .

42. R.I. Gen. Laws § 15-5-16(d)(1) (2003). See also Mo. Rev. Stat. § 452.400(3) (2003) ("The court shall mandate compliance with its order by all parties to the action ...."); Me. Rev. Stat. AnN. tit. 19-A, § 1653(2)(D)(5) (1998 \& Supp. 2004) (The order of the court awarding parental rights and responsibilities must include "[a] statement that violation of the order may result in a finding of contempt and imposition of sanctions ...."). 
MacIntosh ${ }^{43}$ provided that "[mother is] ordered to obtain [daughter's] passport"; and "the parties' children ... are ordered to accompany their [f]ather . . . on the trip to Switzerland." ${ }^{44}$ When the trip did not occur as scheduled, the father initiated an enforcement action against the mother, alleging her noncompliance with this judicial order. In response, the mother argued that the court order "expressly commanded her only to obtain a passport for [the daughter]," and that "the order ... did not put her on notice that she was to do anything [else]." ${ }^{45}$ The MacIntosh court rejected this position, stating that "[a]s the parent with legal custody and authority over her minor daughters, [mother] was impliedly ordered to make reasonable efforts to ensure that the children complied with the scheduled parenting time." ${ }^{\prime 46}$ Therefore, the mother's failure to make reasonable efforts to support the scheduled trip constituted a violation of the custody order, and she was held in contempt of court.

The Indiana legislature has defined the effect of visitation orders in a more restrictive manner. The Indiana visitation enforcement statute provides that a parent whose court-ordered visitation rights have been violated is entitled to a temporary restraining order or injunction, requiring the custodial parent to obey the initial visitation order in the future. ${ }^{47}$ An action for contempt and other equitable enforcement remedies only become available in a second enforcement proceeding, upon proof of the custodial parent's subsequent violation of this injunction. ${ }^{48}$ In this manner, the Indiana statute fails to treat the initial visitation order itself as an injunctive or coercive order. Indeed, the two-step enforcement procedure, requiring the initial entry of an injunction based on past wrongdoing, is parallel to the use of injunctive relief in the tort and contract scenarios described above.

The provisions of the Indiana visitation enforcement statute are exceptional in this regard. Under the laws of most states, illustrated by the ruling in the MacIntosh case, initial custody and visitation orders are regarded as coercive orders of the divorce court whose breach may give rise to

43. 749 N.E.2d 626 (Ind. Ct. App. 2001).

44. Id. at 628-29.

45. Id. at 629-30.

46. Id. at 630 (emphasis added). Notably, the Indiana court in MacIntosh did not refer to the state statute discussed infra at text accompanying notes 47-48. It is not clear that the statute was in effect at the time of the 1997 contempt hearing in this case. See also Bowen v. Bowen, 198 S.E.2d 862, 863 (Ga. 1973) (rejecting mother's "conten[tion] that [mother] cannot be in contempt for the alleged violation because the divorce decree does not order her to perform any act but merely defines the father's visitation rights").

47. See Ind. Code AnN. §§ 31-14-15-1, -2 (LexisNexis 2003).

48. See id. §31-14-15-4. 
equitable remedies for the violation of an injunctive court order, including contempt. The establishment of coercive orders in this manner, in the absence of any finding of wrongdoing by one party, is a special feature of the child custody context. State custody laws require this form of regulation, based on an assumption that established family relationships require protective state action at the time of parental divorce.

\section{PART II: ENFORCEMENT}

Part I analyzed the nature of custody orders as coercive court orders. Part II will explore the issue of enforcement, in particular, the judicial implementation of contempt remedies for the violation of custody orders. As described in Part I, the priority assigned by the family law system to post-divorce parent-child relationships results in the routine entry of coercive court orders. As revealed in this Part, the same protective concern for parent-child relationships also shapes the enforcement doctrines in this field.

\section{A. Noncompliance With Custody Orders}

Judicial orders creating post-divorce parenting plans are generally designed to regulate the conduct of family members for an extended period of time, until the children reach adulthood. A parent may be dissatisfied with custody and visitation orders at the time of divorce, or dissatisfaction may develop over time. State custody laws provide that either parent may seek judicial modification in certain circumstances. ${ }^{49}$ Absent such judicial action, however, the parents remain obligated to perform the duties imposed upon them at the time of divorce.

In some cases, divorced parents fail to comply over time with the terms of their court-ordered parenting plans. The noncompliant parent may be motivated by concern for the children's well-being, ${ }^{50}$ as in the hypothetical

49. See 4 LitTLE, supra note $9, \S 25.05[3]$.

50. See, e.g., Morgan v. Foretich, 521 A.2d 248 (D.C. 1987). See generally Jessica Pearson \& Jean Anhalt, Enforcing Visitation Rights: Innovative Programs in Five State Courts May Provide Answers to This Difficult Problem, Judges' J., Spring 1994, at 2, 6 (discussing the incidence of parental concern about child safety in visitation enforcement cases).

The mother in Morgan was jailed under a contempt order in the District of Columbia after hiding her child from the father whom she considered abusive. Her refusal to comply with the contempt order by revealing her child's location resulted in a lengthy period of incarceration, which ended when Congress enacted a time limit on imprisonments for civil contempt in child custody cases in the District of Columbia. See David J. Harmer, Limiting Incarceration for Civil Contempt in Child Custody Cases, 4 BYU J. PuB. 
case discussed earlier where the noncustodial parent subjected a child to unauthorized elective surgery. Other reasons for noncompliance may include the belief that a custody order is unfair, the desire to inflict harm on a former spouse, or the inability of parents to overcome practical hurdles or to communicate with each other. In the event of noncompliance by one parent, the other has standing to initiate an enforcement proceeding. ${ }^{51}$

An important empirical study of post-divorce litigation, published in 1994, revealed that a significant number of divorced parents returned to court in this manner alleging noncompliance with custody and visitation orders. ${ }^{52}$ The study involved 700 couples with children who obtained divorces in the family court in Cambridge, Massachusetts between 1978 and 1984. The researchers studied the court records for all of these families through 1988, thus tracking their litigation histories for periods ranging from four to ten years.

The Cambridge study reported on the incidence of post-divorce litigation regarding custody, visitation, support and property issues..$^{53}$ The researchers' overall conclusion was that " $[t]$ he amount of relitigation was remarkable; $41 \%$ (287) of the 700 families had relitigated by the end of the data collection ... with a mean of 4.3 motions [per family]." ${ }^{94}$ The report broke down these post-

L. 239, 256-78 (1990) (discussing in detail the facts of the Morgan case and the Congressional response); Randal S. White, Comment, Civil Contempt and Congressional Interference in the Case of Morgan v. Foretich, 95 Dick. L. Rev. 353 (1991); Marcia Coyle, A Question of Contempt, NAT'L L.J., Oct. 30, 1989, at 1 .

51. See 4 RUTKIN, supra note $4, \S 47.01$ [2], at 47-49 ("In all jurisdictions, proceedings to enforce the custody or visitation provisions of a [divorce] decree, or agreement incorporated in a decree, are viewed as an integral part of the court's continuing power to compel performance of its mandates."). As a general rule, jurisdiction over the person of the defendant is required in a contempt proceeding. See CLARK, supra note $9, \S 19.10$, at 848 . There is a split of authority as to whether the jurisdictional base established in an earlier divorce or custody proceeding confers jurisdiction in the custody enforcement hearing. See 4 LitTLE, supra note 9, $\S 25.05[1][\mathrm{b}]$, at 25-136 to -138. Additional jurisdictional issues arise in interstate custody enforcement cases, see Linda D. Elrod, Child Custody Practice and Procedure $§ 15: 14$, at 15-37 to -41 (2004), and international cases, see id. §§ 15:20 to :27.

52. See Amy Koel et al., Patterns of Relitigation in the Postdivorce Family, 56 J. Marriage \& FAM. 265 (1994).

53. The second piece of quantitative information required to understand the incidence of custody enforcement issues is the number of divorces involving the parents of minor children. The rate of divorce in families with children is high. See Robert H. Mnookin, Child, Family, and State 626 (1978) ("Of the nearly one million divorces each year, an estimated $62 \%$ involve children."). See generally GugGenheim, supra note 6, at 134 ("Today, more than 1 million marriages end in divorce each year.").

54. Koel et al., supra note 52, at 270 . There was likely an additional number of families where one parent believed that the other had not complied with the terms of post-divorce custody and visitation orders, was not satisfied with the status quo, but did not bring the matter to the attention of the court. See Ira Daniel Turkat, Child Visitation Interference in Divorce, 14 Clinical Psychol. Rev. 737, 742 (1994) 
divorce motions into subject matter categories: 26.1 percent of the 287 relitigating families raised custody issues; 27.2 percent raised visitation issues; and 88.2 percent raised financial issues (property, alimony and child support combined).$^{55}$ In a further breakdown of child-related issues, 1.7 percent of the relitigating families went back to court in custody contempt cases; 25.1 percent in custody modification cases; 12.5 percent in visitation contempt cases; and 17.4 percent in visitation modification cases. ${ }^{56}$ Thus, a total of 14.2 percent of relitigating families, or 41 of the 700 families studied, raised custody and visitation enforcement (contempt) issues, the subject of this Article. ${ }^{57}$

\section{B. The Public and Private Interests at Stake}

The enforcement of custody or visitation orders, in a proceeding initiated by one parent alleging noncompliance by the other, protects important public and private interests. First, as a general rule in civil litigation, the enforcement of court orders reinforces the credibility of the courts and a general attitude of public deference to judicial authority. Thus, "[t]he judicial system arguably could not survive as an effective institution unless it could punish disobedience of orders or disruption of its proceedings . . .". 58

(citing studies indicating a high incidence of "visitation interference" and calling for more research on the subject); Pearson \& Anhalt, supra note 50, at 3 ("Noncustodial parent groups have complained that visitation interference is widespread and that the increasingly aggressive enforcement of child support obligations has not been matched by an equally aggressive enforcement of visitation rights.").

55. Koel et al., supra note 52, at 271, tbl. 2.

56. Id.

57. Id. Several additional studies have reported on relitigation rates without distinguishing between child access issues and financial issues. See, e.g., Bruce Berger et al., Child Custody and Relitigation: Trends in a Rural Setting, 58 AM. J. ORTHOPSYCHIATRY 604, 606 (1988) (reporting an overall relitigation rate of approximately twenty percent among 884 divorced families with children whose divorces were granted and histories were tracked during the period 1980-1984 in a rural North Carolina county); Deborah Anna Luepnitz, A Comparison of Maternal, Paternal, and Joint Custody: Understanding the Varieties of Post-Divorce Family Life, 1986 J. DivorCe 1, 5 (reporting, in a study of forty-three post-divorce families, that "none of the joint families had relitigated, whereas $56 \%$ of the single custody parents had returned to court at least once to battle over money and visitation") (emphasis added)).

Other studies distinguish between custody issues and financial issues, but do not break down the custody category into modification and enforcement subcategories. See, e.g., Peter Ash \& Melvin T. Guyer, Relitigation After Contested Custody and Visitation Evaluations, 14 Bull. Am. ACAD. Psychiatry \& L. 323, 327 (1986) (reporting, in a study of fifty-eight "high conflict" divorce cases, that nineteen percent of families returned to court over custody issues, seventeen percent over visitation issues, and thirty-six percent over child support issues); Laurie Kramer \& Amanda Kowal, Long-Term Followup of a CourtBased Intervention for Divorcing Parents, 36 FAm. \& Conciliation CTS. Rev. 452, 455-56 (1998).

58. Margit Livingston, Disobedience and Contempt, 75 WASH. L. Rev. 345, 400 (2000). The 
Professor Lawrence Nolan applied this general observation to the specific context of visitation orders, as follows: "The public . . . has an interest. Visitation orders are not like money judgments. Noncompliance with a visitation order is ... showing disrespect to the court." 59 Within this frame of reference, the entry of remedial orders in custody and visitation enforcement proceedings serves to strengthen the judicial system.

Beyond this public interest in maintaining respect for the institution of the courts, the enforcement of custody and visitation orders vindicates private interests as well. ${ }^{60}$ Both the complaining parent and the children are directly affected by the other parent's noncompliance with a court-ordered parenting plan. From the children's perspective, the initial parenting plan orders were deemed by the court at the time of their entry to serve the children's interests. Therefore, a significant variation by one parent from the terms of the plan, to which the other parent objects, is assumed to be contrary to the children's interests. $^{61}$ In addition, one parent's noncompliance with the terms of a parenting plan clearly interferes with the established rights of the other. The complaining parent initiates a custody or visitation enforcement proceeding in order to vindicate these private family interests.

If the court determines that one parent has violated the terms of a courtordered parenting plan, the court must then select and impose appropriate remedies and sanctions. The general purpose of such remedial action is vindication of the public and private interests described in this Section.

\section{Remedies}

Upon finding that one parent has violated the terms of a parenting plan, the court must establish remedial goals, and impose sanctions designed to achieve them. Most enforcement cases involve the noncompliance by one parent with residential parenting orders, ${ }^{62}$ and the most frequently stated goal

disobedience of court orders, including custody orders, is referred to as "indirect" contempt of the court, and the form of contempt that involves misbehavior in the courtroom is labeled "direct" contempt. See id. at 349-54.

59. Laurence C. Nolan, Beyond Troxel: The Pragmatic Challenges to Grandparent Visitation Continue, 50 Drake L. Rev. 267, 285 (2002). See also 4 Little, supra note 9, § 25.05[2][a], at 25-146 ("[T] he notion persists that the flouting of the [custody] court's authority must be vindicated in order to maintain respect for the courts and their directives.").

60. See generally Livingston, supra note 58, at 401 (describing the manner in which the law of contempt protects the private interests of the complaining party).

61. See Nolan, supra note 59, at 285.

62. Although less common than the enforcement of residential custody orders, parents may also seek 
is to bring the violator into compliance in the future. The court may, however, articulate additional goals in this context, most notably, the punishment of a parent for past violations or compensation of the complaining parent for his or her resulting losses. Various remedies, including civil and criminal contempt, are tailored to achieve each of these goals.

Under the laws of most states, the range of judicial remedies for the violation of custody and visitation orders is wide. First, contempt remedies become available whenever parental noncompliance is viewed as the violation of a coercive or injunctive order of the court. Under general contempt doctrines in every state, the courts are empowered to directly enforce their injunctive orders. ${ }^{63}$ Typical sanctions under these general contempt doctrines are a fine and imprisonment, in amounts and for time periods that may be limited by state law. In the family law area, statutes in more than half of the states detail the availability of contempt remedies in custody and visitation enforcement cases. ${ }^{64}$

the enforcement of orders governing post-divorce decision making responsibility and orders governing other aspects of parental behavior. See Lane v. Lane, 779 A.2d 859, 861 (Conn. App. Ct. 2001) (affirming contempt adjudication for mother's violation of a court order that "the [mother] shall not initiate medical, therapy or educational care for the children without the prior written consent of the [father] except in the case of emergency"); Nelson v. Nelson, 598 N.Y.S. 609, 611 (N.Y. App. Div. 1993) (involving the enforcement of custody provisions requiring the mother to "refrain from engaging in harassing conduct" and "consult with [the father] concerning . . . the children's education and psychological counseling"); Ryder v. Ryder, No. 2001CA00190, 2002 WL 258218, *1 (Ohio Ct. App. Feb. 19, 2002) (affirming contempt order based on the mother's failure to "communicate with" the father).

63. See generally Ronald L. Goldfarb, The Contempt Power 9-25 (1963) (tracing the rise and establishment of the contempt power of the courts in England and the United States); Livingston, supra note 58, at 356-78 (tracing the history of contempt law in the United States).

Critics of broad judicial contempt powers highlight the inherent intrusion on the individual autonomy of contemnors involved in their exercise. See GoldFARB, supra note 63, at 3; Harmer, supra note 50, at 245 ("Although many courts and commentators have uncritically accepted 'the ... view that contempt powers are a necessary and inherent element of judicial power,' modern research finds them neither inherent nor necessary." (citation omitted)). Conversely, proponents emphasize the interests of the complainant whose rights under an existing court order have been violated. See Livingston, supra note 58, at 348 ("[A]lthough alleged contemnors are certainly entitled to adequate procedures before the court may impose sanctions [in a contempt proceeding], successful plaintiffs are equally deserving of an effective remedy without undue delay.").

64. See Cal. Fam. Code $\S 290$ (West 2004); Colo. Rev. Stat. § 14-10-129.5(2)(e) (2004); Conn. Gen. Stat. Ann. § 46b-87 (West 2004); Del. Code Ann. tit. 13, § 728(b)(5) (1999); Haw. Rev. Stat. ANN. § 571-8.5 (LexisNexis 1999); 750 Ill. Comp. Stat. ANN. §§ 5/607.1, /611 (LexisNexis 1999); Ind. Code Ann. § 31-17-4-8(1) (LexisNexis 2003); Iowa Code Ann. § 598.23(1)(West 2001); Ky. Rev. Stat. AnN. § 403.240(2) (LexisNexis 1999); La. Rev. Stat. Ann. § 13:4611 (Supp. 2005); Me. Rev. Stat. AnN. tit. 19-A, § 1653(7) (1998); Mich. Comp. Laws Ann. §§ 552.641(1)(b), 644 (West 2002); Mo. Rev. Stat. § 452.400(3) (2000 \& Supp. 2004); Neb. Rev. Stat. § 42-364.15 (2004); Nev. Rev. Stat. AnN. $\S \S 125$ C.030, .040 (LexisNexis 2004); N.C. Gen. Stat. § 50-13.3(a) (2003); Ohio Rev. Code AnN. $\S 2705.031(B)(2)$ (West 2006); Okla. Stat. Ann. tit. 43, § 111.1(C)(1) (West 2001); Or. Rev. Stat. 
Besides contempt, the habeas corpus doctrine has traditionally provided a remedy for the violation of custody and visitation orders in certain circumstances. ${ }^{65}$ The parent entitled to custody has standing to initiate a proceeding, wherein the other parent must produce the child in court. Professor Arnold Rutkin has noted the limitations of this remedy for many common custody enforcement fact patterns:

Habeas corpus will not be an effective remedy in all situations. When the period of wrongful detainment is very short, the issue may become moot before the writ can be processed. Additionally, a writ of habeas corpus will not alone deter future interference with custody or visitation rights. ${ }^{66}$

Another potential remedy for the violation of parenting plan orders involves the modification of certain terms of the parents' divorce decree. The terms subject to possible modification are the alimony and child support provisions, ${ }^{67}$ or even the violated custody and visitation orders. ${ }^{68}$ These modification sanctions, however, are controversial and are not uniformly accepted by state legislatures and courts as remedies for noncompliance with custody and visitation orders. ${ }^{69}$

The courts in many states have the authority to require noncompliant parents to post a bond, which is forfeitable to the court in the event of any future violation of the initial custody order. ${ }^{70}$ The primary goal here is to coerce compliance by tying a defined financial sanction to subsequent noncompliance.

In recent years, a number of state legislatures have added new remedies to their custody statutes, in order to provide more flexible options to the courts

$\S 107.135(14)(b)(B)$ (2005); 23 Pa. Cons. STAT. § 4346 (2004); R.I. GEN. LAWs § 8-10-38 (1997); S.C.R. Proc. Fam. Ct. 27 (2005); S.D. Codified Laws $\S \S 25-4 A-1,-2$ (1999); Tex. Fam Code AnN. $\S 157.001$ (b) (Vernon 2002); Vt. Stat. Ann. tit. 15, $\S$ 603, 668(d) (2002); Wash. Rev. Code AnN. $\S 26.09 .160$ (1) (West 2005); W. VA. Code AnN. $\S \S 48-1-304,51-2 A-9$ (LexisNexis 2004); Wyo. Stat. ANN. § 20-2-204(b) (2005).

65. See 3 RutKIN, supra note $4, \S 32.11[2][\mathrm{b}]$; James A. Albert \& Gregory A. Brodek, Habeas Corpus - A Better Remedy in Visitation Denial Cases, 41 Me. L. Rev. 239, 252-54 (1989) (comparing effectiveness and other aspects of habeas corpus and contempt remedies in visitation interference cases).

66. 3 RUtKIN, supra note $4, \S 32.11[2][\mathrm{b}]$, at 32-419 (italics omitted).

67. See id. § 32.11[2][d].

68. See ALI PrinciPLES, supra note $3, \S 2.19$ Reporter's Notes cmt. c (collecting state statutes that "include modification of the underlying order among the possible remedies for violation of a custody order or parenting plan").

69. See id.

70. See 3 RutKIN, supra note 4, § 32.11[2][c]; 4 LittLE, supra note 9, § 25.05[5]. 
in carrying out the responsibility of custody enforcement. ${ }^{71}$ For example, the Colorado statute governing "[d]isputes concerning parenting time" ${ }^{72}$ contains versions of the contempt, modification and security remedies described above. In addition, the statute provides for court-mandated mediation, parental education, family counseling, makeup parenting time, civil fines payable to the state treasurer, the payment of attorney fees, court costs and expenses to the petitioning parent, and "[a]ny other order that may promote the best interests of the child." ${ }^{, 73}$ Additional remedies appearing in the corresponding provisions of other state family codes include "other economic sanctions which may be decided on a case-by-case basis," 74 suspension of the noncompliant parent's driver's license ${ }^{75}$ community service,${ }^{76}$ and a warrant or writ issued by the court to involve law enforcement personnel in the custody enforcement effort. ${ }^{77}$

Notably, the list of remedies does not routinely include the denial of future custody rights to the parent who violated custody orders in the past. The state interest in protecting children's relationships with their parents, reflected in the initial coercive order of the divorce court, also supports their maintenance over time except in extreme cases. ${ }^{78}$

The place of the traditional contempt remedy within the elaborate array of remedial options in the custody enforcement field varies from state to state. One model, illustrated by the Colorado statute summarized above, includes contempt as an alternative to specified noncontempt remedies, ${ }^{79}$ including the

71. See ALI Principles, supra note $3, \S 2.19$ Reporter's Notes cmts. a-d.

72. Colo. Rev. Stat. § 14-10-129.5 (2004).

73. Id. § 14-10-129.5(2)(h). Besides the enforcement tools available in the family court, some jurisdictions establish tort and criminal causes of action relating to the interference with parental rights. See ElRoD, supra note 51, § 15:17 (discussing tort doctrines); 3 RutKIn, supra note 4, § 32.11[3] (discussing criminal law). For example, the Colorado "parenting time dispute" statute discussed in the text provides that "[n]othing in this section shall preclude a party's right to a separate and independent legal action in tort." Colo. Rev. Stat. § 14-10-129.5(4).

74. N.J. STAT. AnN. § 2A:34-23.3(e) (West 2000).

75. See 23 Pa. Cons. Stat. $§ 4346(a)(4)(2004)$.

76. See N.J. Stat. Ann. § 2A:34-23.3(b).

77. See Cal. Fam. Code $\S 3131$ (West 2004); Mo. Rev. Stat. $\$ 452.425$ (2000) (“Any court order for the custody of, or visitation with, a child may include a provision that the sheriff . . shall enforce the rights of any person to custody or visitation ....”); N.J. Cт. R. 5:3-7 (2006); OR. Rev. Stat. § 107.437 (2005) (authorizing "order of assistance" to enforce custody, but not visitation, rights); 3 RUTKIN, supra note $4, \S 32.11[2][\mathrm{g}]$.

78. See ALI Principles, supra note $3, \S 2.11$ (describing circumstances in which the court may modify a custody order by terminating the custodial responsibility of a parent).

79. Custody enforcement schemes that include the contempt remedy in this manner as an alternative to specified noncontempt remedies follow a pattern described by Professor Dobbs as to the general enforcement of coercive court orders: 
posting of a bond, modification of the divorce decree, family education programs, and mediation. Thus, the list of remedies under this statute also includes " $[\mathrm{a}] \mathrm{n}$ order finding the parent who did not comply with the parenting time schedule in contempt of court and imposing a fine or jail sentence." $\$ 0$

A second category of state custody enforcement laws establishes a different relationship between the contempt remedy and other statutory enforcement mechanisms. ${ }^{81}$ Namely, the other enforcement devices are included as sanctions for contempt, along with the traditional sanctions of a fine or jail sentence. For example, the Michigan statute provides a lengthy list of sanctions available in "civil contempt proceeding[s] to resolve . . . dispute[s] concerning parenting time." ${ }^{\prime 2}$ Upon finding a parent in contempt, the court may "modify the parenting time order ... [;] [o]rder that makeup parenting time be provided ... [;] [o]rder the parent to pay a fine of not more than $\$ 100$. . . [;] commit the parent to the county jail . . [;] condition the suspension of [a] license ... upon noncompliance with an order for makeup and ongoing parenting time ... [;] [and/or] order the parent to participate in a community corrections program . . .." 83 Under this model, the range of

[E]quitable decrees are traditionally in personam, that is, personal orders to the defendant to act in a particular way. ... Because they are personal orders, they are often enforced coercively, through the contempt power. They may also be enforced in other, less drastic ways, however. DoвBS, supra note $24, \S 2.8(1)$, at 130. See generally Livingston, supra note 58 , at 421 ("Of course, not every order lends itself to noncontempt enforcement mechanisms .... In some cases, the defendants' personal performance will be required to ensure that the proper result is attained. If the defendants simply refuse to comply and other enforcement mechanisms are not practicable, contempt sanctions may be the only route for achieving enforcement of the order.").

80. Colo. Rev. Stat. § 14-10-129.5(2)(e) (2004). This statute provides no guidance to the courts about the appropriate amount of a fine, or length of a jail sentence. Family court contempt provisions in other jurisdictions fill these numerical gaps. For example, the South Dakota statute limits fines to $\$ 1000$, and jail sentences to three days. See S.D. Codified Laws § 25-4A-5 (1999).

81. A final approach to the codification of contempt doctrine for the purpose of child custody and visitation enforcement involves legislative silence. The family codes in some jurisdictions make no reference to contempt remedies, leaving the custody courts to determine the proper application of the state's general contempt law in custody cases.

82. Мich. Comp. Laws AnN. § 552.644(2) (West 2002).

83. Id. See also Me. Rev. StAt. AnN. tit. 19-A, § 1653(7) (1998) ("If the court finds that a parent has violated a part of the order, the court may find that parent in contempt and may . . [o]rder that additional visitation be provided for a parent to take the place of visitation that was wrongfully denied; or ... [o]rder a parent found in contempt to pay a forfeiture of at least \$100.”); 23 PA. Cons. STAT. § 4346(a) (2004) (authorizing fines, imprisonment, probation, and the revocation of licenses as sanctions for contempt); WaSh. Rev. Code ANN. § 26.09.160(2)(b) (West 2005) (authorizing make-up residential time with the children, reimbursement of the other parent's attorney fees and expenses, as well as fines and imprisonment, as sanctions for contempt). 
sanctions for contempt in child custody enforcement cases far exceeds the traditional contempt sanctions of fines and imprisonment.

In most reported custody and visitation enforcement cases, the complaining parents sought sanctions associated with the remedy of contempt under state law. The selection of remedy and imposition of sanctions by the court in each case depended on the circumstances of the family, the nature of the parenting plan violations, and the remedial goals set by the court. As described in the remainder of this Article, contempt remedies in the field of child custody have been used by the courts in a flexible manner to achieve the important goals associated with the enforcement of court-ordered parenting plans.

\section{Judicial Discretion in Contempt Cases}

Trial courts exercise discretion as to all aspects of a custody contempt proceeding, and the general standard of review on appeal is the abuse of discretion standard ${ }^{84}$ This aspect of custody enforcement doctrine involves the application of general rules governing judicial contempt proceedings to the family law setting.

In custody enforcement proceedings, the court must first determine whether the allegedly noncompliant parent willfully violated the terms of established parenting plan orders. As to this threshold determination, recurring issues on appeal involve the clarity of the custody terms and the willfulness of the contemnor's failure to comply with them. For example, the "clarity" issue provided the basis for reversal of a mother's conviction for contempt in the case of Kranis v. Kranis. ${ }^{85}$ There, the appellate court ruled that a term in the custody decree providing for "reasonable visitation" was not "clear and definite," and the trial court's contrary conclusion on this key issue constituted an abuse of discretion. ${ }^{86}$

A second appealable element in the threshold determination of unlawful conduct involves the willfulness of the parent's violation of the court-ordered parenting plan. ${ }^{87}$ In the case of In re Marriage of S.G. and V.G. ${ }^{88}$ for

84. See ElRod, supra note 51, § 15:6, at 15-19 (2004).

85. 313 So. 2d 135 (Fla. Dist. Ct. App. 1975).

86. Id. at 139. See also 3 RutKIN, supra note 4, §32.11[2], at 32-415 to 416 (discussing cases involving claims that custody and visitation orders were too vague to be enforceable).

87. See 4 LitTle, supra note $9, \S 25.05[2][\mathrm{c}]$, at 25-159 to $-162 ; 4$ RutKin, supra note 4, $\S 47.06[2]$, at 47-69 n.10 (collecting and summarizing cases involving the issue of willful noncompliance). Numerous cases involving the willfulness of parental noncompliance with custody and visitation orders involve older children who were, according to the allegedly noncompliant parent, unwilling to spend time 
example, the trial court found that a mother had good cause for withholding scheduled visitation, due to her child's illness. On appeal, the S.G. court affirmed the trial court's conclusion that noncompliance with the custody order in these circumstances had not been willful, ${ }^{89}$ and that the mother was not guilty of contempt.

Upon determining that a parent willfully violated the clearly-stated terms of a custody order, the court must select appropriate sanctions. ${ }^{90}$ Discretionary elements in the formulation of sanctions for contempt include the amount of fines and the length of jail sentences, which may be limited by statute, ${ }^{91}$ the conditions associated with indeterminate fines and jail sentences, ${ }^{92}$ and the imposition of sanctions other than fines and jail sentences. ${ }^{93}$ In addition, the court may find a parent to be in violation of a custody order, but decline to impose any sanction. The trial court in Hawkins v. Mullins,${ }^{94}$ for example, found the mother to be in contempt of court "for allowing a prohibited third party to be present during a visitation exchange," 95 but did not impose any sanction. The appellate court in Hawkins affirmed this decision, stating that "[e]ven though a party is found to have violated a court order, the question of whether or not to impose sanctions remains a matter for the [trial] court's discretion." ${ }^{96}$

with the other parent. See 4 LitTLE, supra note 9, § 25.05[2][c], at 25-159.

88. 824 S.W.2d 109 (Mo. Ct. App. 1992).

89. Id. at 110. See also In re Marriage of Herkert, 615 N.E.2d 833, 836-37 (Ill. App. Ct. 1993) (stating that "[w]hether ... a party is guilty of contempt rests within the sole discretion of the trial court," in affirming a finding that mother's failure to make children available for visitation with father was not willful); Midyett v. Midyett, 744 So. 2d 669, 674 (La. Ct. App. 1999) ("“T]he facts leading up to the lost visitation ... do not rise to the level of willful, contemptuous behavior warranting reversal of the trial court's abundant discretion.") (emphasis added).

90. See Elrod, supra note 51, § 15:7, at 15-23 ("The court has discretion and some flexibility in fashioning the appropriate remedy for civil contempt.").

91. See, e.g., S.D. Codified Law § 25-4A-5 (1999) (imposing limits on the amount of fines and length of jail sentences for "violation of the custody or visitation provisions of a court decree").

92. See infra text accompanying notes $132-52$.

93. As described above, see text accompanying notes 79-80, the custody enforcement statutes in some states provide for contempt sanctions beyond the traditional sanctions of a fine or imprisonment. See also In re Marriage of Almquist, 704 N.E.2d 68, 69 (Ill. App. Ct. 1998) (affirming trial court's determination of mother's criminal contempt for interfering with father's right to talk to children by telephone and her "sentence[ ] . . . to two years of court supervision").

94. 597 S.E. 2 d 897 (S.C. Ct. App. 2004).

95. Id. at 898 .

96. Id. at 900. See also In re Marriage of Knutson, 413 N.W.2d 593, 598 (Minn. Ct. App. 1987) (ruling that "trial court did not abuse its discretion in staying the consequences of contempt" against mother in a visitation enforcement proceeding). But see In re Marriage of Wolk, 828 P.2d 634, 636 (Wash. Ct. App. 1992) (construing the word "shall" in the state custody contempt statute to remove judicial discretion 
By way of contrast, the trial court's decision about appropriate sanctions for contempt received less deference from the appellate court in the case of Nelson v. Nelson. ${ }^{97}$ There, the initial custody order required the mother "to bring the children to . . . scheduled visitation dates."98 The trial court found the mother in contempt for failing to comply with the visitation schedule on two occasions, and imposed as sanctions a fine and an award of attorney fees to the father. On appeal, the Nelson court affirmed the trial court's contempt determination based on the missed visitation, but reversed the decision regarding sanctions. According to the appellate court, "a monetary fine is simply too harsh a punishment under the circumstances ... ; a warning to respondent concerning the consequences of future transgressions of this nature is sufficient." 99

The appellate court in Nelson also reversed the trial court's entry of two additional contempt citations against the mother, relating to other provisions of the custody order. Those provisions required the mother to "refrain from engaging in "harassing' conduct" and "consult with [father] concerning ... the children's educational and psychological counseling." " The trial court in Nelson determined that the mother had violated the "harassment" requirement when she "made two complaints to the State child abuse hotline regarding [father] that were ultimately determined to be unfounded,"101 and that she had also violated the "consult with father" term of the custody order. On appeal, however, the appellate court ruled that the trial court abused its discretion in making these determinations, and reversed the contempt citations against her.

Thus, trial court decisions regarding both the violation of custody orders and the appropriate sanctions for contempt are reviewable on appeal under the abuse of discretion standard. Additional grounds for appeal in many custody enforcement cases turn on the characterization of the contempt citation as either civil or criminal, a matter discussed in the next section.

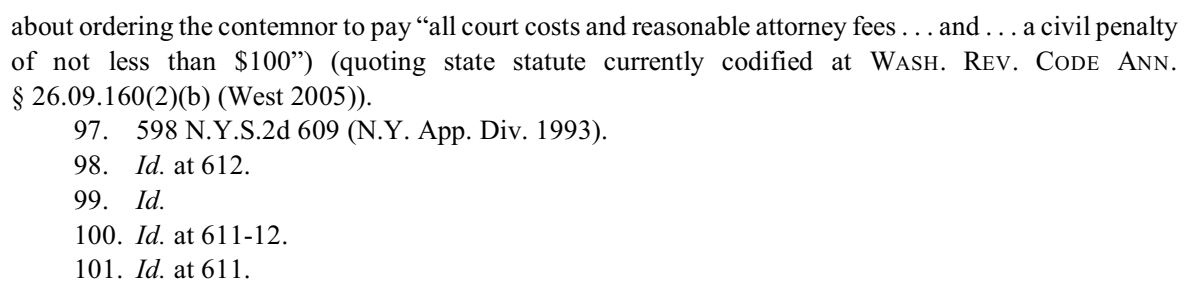




\section{E. The Distinction Between Civil and Criminal Contempt}

A basic dichotomy in general contempt doctrine draws a line between "civil contempt" and "criminal contempt." The distinction has important consequences in the field of custody enforcement. The characterization of a contempt order as "civil" or "criminal" is based primarily on the nature of the sanctions imposed upon the contemnor, which reflect the purpose of the order. ${ }^{102}$

The type of sanction typically associated with criminal contempt is the determinate jail sentence or fine payable to the court, intended to punish the contemnor for disrespect shown to the court in disobeying its prior order. ${ }^{103}$ For example, an Ohio appellate court provided the following description of the criminal contempt order in a child visitation case:

[T] he trial court found [mother] guilty of willful contempt for violating the court's visitation order ... and sentenced her to 30 days in jail and fined her $\$ 250$. The purpose of the prison sentence and fine was punitive. ... [T] he trial court expressed its disgust with the parents ... and stated on the record that it was "done messing with this case" and that this was "the last straw." 104

Based on this record, the appellate court concluded that the contempt order was criminal, not civil, in nature.

By way of contrast, the sanctions for civil contempt are designed to be remedial rather than punitive, by coercing the contemnor's future compliance with the original court order or compensating the private party who suffered damages as a result of past violations. The most common coercive sanctions are the indeterminate jail sentence or a serial fine that is terminable upon the contemnor's compliance with the original court order. ${ }^{105}$ For example, the court may impose a daily fine upon the parent who unlawfully retains the physical custody of children, payable to the court each day until the children are returned to the other parent. The second category of remedial sanctions is compensatory in purpose, and often involves the payment of fines to

102. In Hicks v. Feiock, 485 U.S. 624 (1988), a child support enforcement case, the Supreme Court held that the characterization of a contempt as civil or criminal turns upon the nature of the sanctions imposed, highlighting the distinctions described in the text. See generally Harmer, supra note 50, at 248 (criticizing the sanction-based test for distinguishing between civil and criminal contempt).

103. FisCHER, supra note $29, \S 312$ [c][i], at 724 .

104. Ryder v. Ryder, No. 2001CA00190, 2002 WL 258218, at*2 (Ohio Ct. App. Feb. 19, 2002) (citations omitted) (quoting the trial court transcript).

105. See infra text accompanying notes 130-50 (discussing coercive contempt orders in custody enforcement cases). 
individuals injured by the contemnor's unlawful behavior. ${ }^{106}$ Thus, the parent who violates a custody order may be required to reimburse the other parent for his or her resulting losses including, for example, expenses incurred in enforcing the order.

Several important legal consequences follow from the characterization of a contempt adjudication as either criminal or civil. First, although a judicial hearing is required in every contempt case, ${ }^{107}$ the additional procedural requirements are more onerous in criminal contempt proceedings. Many of the procedural protections guaranteed under the U.S. Constitution to defendants in criminal trials are also required in criminal contempt cases. ${ }^{108}$ Thus, the accused contemnor enjoys a presumption of innocence, ${ }^{109}$ and the heightened burden of proof beyond a reasonable doubt applies in criminal contempt cases. ${ }^{110}$ Similarly, the right to a jury trial is guaranteed in many criminal contempt proceedings, but not in civil contempt cases. ${ }^{111}$ Additional procedural guarantees relate to the form of notice of the contempt proceeding, ${ }^{112}$ and the opportunity to prepare a defense, ${ }^{113}$ and confront

106. See infra text accompanying notes 151-72 (discussing compensatory contempt orders in custody enforcement cases).

107. See 4 RutKin, supra note $4, \S 47.06[2]$, at 47-72.

108. John F. DobByn, InJunctions IN A NuTShell 219-22 (1974).

109. White, supra note 50, at 357.

110. See, e.g., In re Marriage of Ruchala, 567 N.E.2d 725, 730 (Ill. App. Ct. 1991) (reversing mother's contempt citation for violating visitation order); Phillips v. Iowa Dist. Ct., 380 N.W.2d 706, 709 (Iowa 1986) (same).

111. See, e.g., Curlee v. Howle, 287 S.E.2d 915 (S.C. 1982) (holding that the contempt was civil and no jury trial was required, where father's sentence of one year in prison for violating a custody order was terminable upon his payment of damage award to mother). In Bloom v. State, 391 U.S. 194 (1968), the Supreme Court ruled that the right to a jury trial is not constitutionally guaranteed in all criminal contempt cases, but only in those where the sanctions for contempt indicate a serious, not petty, offense. This principle was applied in the visitation enforcement case of McDonald v. McDonald, 850 So. 2d 1182, 1192 (Miss. Ct. App. 2002), where the absence of a jury trial provided no basis for reversing the father's criminal contempt conviction for violating a visitation order, because the contempt was characterized by the appellate court as a "petty crime."

112. See Landingham v. Landingham, 685 So. 2d 946, 951 (Fla. Dist. Ct. App. 1996) (requiring notice in the form of an order to show cause to mother who violated a custody order restricting her relocation, because the contempt proceeding was criminal in nature).

113. See In re Marriage of Vanderpool, 634 N.E.2d 11, 12 (Ill. App. Ct. 1994) (listing notice, opportunity to answer and prepare a defense, and burden of proof beyond a reasonable doubt as procedural protections required in criminal contempt proceeding in visitation enforcement case). 
witnesses. ${ }^{14}$ The failure to provide any of these protections constitutes reversible error in criminal contempt cases. ${ }^{115}$

The double jeopardy rule is another constitutional protection for criminal defendants that has been extended to the criminal contempt context. For example, the father in State v. Hope ${ }^{116}$ successfully invoked the double jeopardy rule to prevent his prosecution for the crime of kidnapping based on the abduction of his child for a period of five months. According to the court, a prior adjudication of the father's criminal contempt in the family court, based on the same wrongful conduct, barred the subsequent prosecution in criminal court. ${ }^{17}$

The civil/criminal distinction in the law of contempt has ramifications in other substantive law contexts, for the parent who has been cited for the violation of a custody order. For example, a provision of the Bankruptcy Act automatically stays certain civil litigation matters in state court, pending the outcome of bankruptcy proceedings. ${ }^{118}$ This automatic stay extends to civil contempt orders, but not to criminal contempt orders. The state court in Arkansas applied this federal rule in the family law case of Hutchins $v$. Hutchins. ${ }^{19}$ There, the court refused to suspend a contempt citation, issued

114. See ELRoD, supra note $51, \S 15.5$, at $15-17$ to -18 (listing the right to a jury trial, right to counsel, presumption of innocence, standard of proof beyond a reasonable doubt, and the right to confront witnesses as procedural protections required in criminal contempt proceedings).

115. The amount of certainty required about the nature of the contempt proceeding, in child custody and visitation cases where due process violations are raised on appeal, seems to vary widely. Compare Korolko v. Korolko, 803 S.W.2d 948, 949 (Ark. Ct. App. 1991) (ruling that trial court's failure to mention the heightened burden of proof beyond a reasonable doubt before imposing a fixed, six-month jail sentence did not constitute error, because "[n]othing in the record indicates that the chancellor was unaware of the proper burden of proof in this criminal contempt proceeding") and Lo v. Lo, 878 So. 2d 424, 426 (Fla. Dist. Ct. App. 2004) ("[G]iven the ambiguity of the proceedings below, and failure of the trial court to afford the procedural safeguards [required] if the proceeding was intended to be criminal in nature, we are compelled to reverse and remand this case ....").

116. 449 So. 2 d 633 (La. Ct. App. 1984).

117. Id. at 636. See also State v. Kimbler, 509 N.E.2d 99, 102 (Ohio Ct. App. 1986) (ruling that double jeopardy did not bar father's prosecution for child stealing even if earlier contempt adjudication was characterized as criminal, because "although arising out of some of the same conduct... [the crime of child stealing was] predicated upon different elements"); Ex parte Jones, 36 S.W.3d 139 (Tex. Ct. App. 2000) (ruling that double jeopardy did not bar mother's criminal prosecution for custodial interference, because her earlier contempt adjudication was characterized on appeal as civil).

The Illinois statute governing the "[e]nforcement of visitation orders" expressly disallows the entry of "a contempt order for visitation abuse against any person for the same conduct for which the person was convicted of unlawful visitation interference [under the criminal code]." See 750 Ill. Comp. Stat. Ann. 5/607.1(g) (LexisNexis 1999).

118. See 11 U.S.C. $\S 362(2000)$.

119. 954 S.W.2d 249 (Ark. 1997). 
in an earlier visitation enforcement proceeding against the father who subsequently filed for bankruptcy, because the contempt was criminal in nature.

Although the characterization of a contempt proceeding and contempt order as civil or criminal has important ramifications for the contemnor during the contempt hearing and thereafter, ambiguity exists in many cases as to this important matter. Often, the underlying contempt statutes, ${ }^{120}$ the parties' pleadings, and the courts' orders all fail to clearly characterize contempt proceedings as criminal or civil in nature. The issue, then, is raised only after the fact, when some differing consequence between the two is at stake. According to one scholar in the field of injunctions, "[n]inety percent of the malfunctions in the system of contempt result from confusion . . . between these two types of contempt." ${ }^{\text {"121 }}$ The confusion is apparent in many custody enforcement cases.

One factor contributing to the blurred line between civil and criminal contempt involves the absence of formal indicators in most criminal contempt cases that the proceeding is "criminal" in nature. The "criminal contempt" discussed here is not a crime prosecutable by the state in criminal court. ${ }^{122}$ Rather, just like the civil contempt proceeding, a criminal contempt case is usually initiated by a private party in the civil court where the initial injunctive order was issued. In the field of custody enforcement, the complaining parent returns to the custody court to allege the contempt, whether criminal or civil, of the other parent who failed to comply with an initial custody order. ${ }^{123}$

120. Although the custody contempt statutes in some jurisdictions include separate provisions for civil and criminal contempt, see, e.g., N.C. GEN. STAT. § 50-13.3(a) (2003) (“An order providing for the custody of a minor child is enforceable by proceedings for civil contempt, and its disobedience may be punished by proceedings for criminal contempt, as provided in [the general state statute governing criminal contempt].”), many do not. For example, the Colorado statute regarding enforcement of parenting time orders simply provides for the entry of "[a]n order finding the parent who did not comply with the parenting time schedule in contempt of court and imposing a fine or jail sentence." Colo. Rev. Stat. $\S 14-10-129.5(2)(\mathrm{e})(2004)$.

121. DobByn, supra note 108, at 217.

122. An additional layer of complexity exists in states that include contempt as a misdemeanor or felony offense within their criminal codes. See, e.g., People v. Wyne, 607 N.Y.S.2d 102 (N.Y. App. Div. 1994) (upholding father's conviction for the separate crimes of custodial interference and criminal contempt under the state penal code).

123. See Fontana v. Fontana, 426 So. 2d 351, 353 (La. Ct. App. 1983) (rejecting father's claim in a visitation enforcement case that "the [criminal] contempt proceeding could not be initiated by [mother] and had to be initiated by the district attorney or the court on its own motion"). All of the other cases discussed in this Section involve an assumption that the complaining parent had standing to initiate an action for either civil contempt or criminal contempt. But see DoBBYN, supra note 108, at 218 ("“T]he 
Another factor that contributes to ambiguity in characterizing contempt orders involves the expansive judicial goals in many contempt cases. The distinction between civil and criminal contempt becomes blurry when a contempt order is intended to serve both punitive (associated with criminal contempt) and remedial (associated with civil contempt) purposes. For example, the Supreme Court of Arkansas highlighted the apparently overlapping purposes of the contempt order in a visitation enforcement case, stating:

No doubt the two purposes [served by civil and criminal contempt adjudications, respectively] often merge as we think they do in this case. It appears from the wording of the [trial] court's order that the [father] was punished because he disobeyed the court's mandate (that is, to preserve the dignity of the court) and also to insure cooperation of the petitioner in the future (that is, to enforce the rights of [the mother]). ${ }^{124}$

A related source of ambiguity is the failure of trial judges to maintain the bright doctrinal line drawn between the sanctions available for criminal and civil contempt, respectively. Since the characterization of a contempt order depends primarily upon the sanctions imposed by the court, ${ }^{125}$ this type of blurring is inherently confusing. For example, the ambiguous contempt order in the South Carolina case of Poston v. Poston ${ }^{126}$ provided that the mother, who had violated prior orders that she have no contact with her children, "shall be sentenced to 120 days incarceration but may purge herself of contempt by strict compliance with [the no-contact orders]." 127 The mother appealed on the ground that the contempt adjudication was criminal in nature, so that the trial court's failure to apply the heightened standard of proof beyond a reasonable doubt constituted reversible error. Although the intermediate appellate court in Poston accepted the mother's position on this issue, the state high court did not. According to the South Carolina Supreme Court, "[t]he contempt order is . . . a hybrid because the sanction has

criminal contempt process is considered an action separate and distinct from the original action in which the injunction was issued. It is prosecuted, not by the [other private party], but by the judge himself, or an officer of the court.").

124. Songer v. State, 364 S.W.2d 155, 157 (Ark. 1963) (rejecting father's claim that the trial court had improperly failed to apply the reasonable doubt standard required in criminal contempt cases). See generally Livingston, supra note 58, at 376 ("The [Supreme] Court emphatically rejected any attempt to classify contempts based on their underlying purpose, noting that any given contempt serves both remedial and punitive purposes to some extent.") (citing Hicks v. Feiock, 485 U.S. 624 (1988)).

125. See supra text accompanying notes 102-06.

126. 502 S.E.2d 86 (S.C. 1998).

127. $I d$. at 88 (quoting the trial court order). 
characteristics of both civil and criminal contempt."128 Specifically, the definite period of the sentence suggested a criminal sanction imposed for a punitive purpose, but the purge provision indicated a coercive purpose to be achieved via civil contempt. The Poston court remanded the case to the trial court to "clarify its intent and issue an order setting forth a contempt sanction that is either clearly criminal or clearly civil." 129

Thus, the dual systems of civil and criminal contempt, and the similarities between the two types of judicial proceedings and orders, may lead to ambiguity about the nature of the contempt order in cases where the parties' pleadings and the courts' orders do not clarify this issue. This lack of clarity complicates the enforcement of custody and visitation orders in many cases.

\section{F. Coercive Civil Contempt Remedies in Child Custody Cases}

Based on the "civil" label used by the parties and the courts, the nature of the sanctions imposed, and the explicit goals emphasized in judicial opinions, the majority of contempt cases in the family law area appear to fall into the civil contempt category. Thus, "[a]lthough criminal contempt may be appropriate in some custody matters, it is not as common as a civil contempt proceeding." 130 Furthermore, as between the two types of remedial sanctions available for civil contempt, coercive sanctions seem to be employed more readily than compensatory sanctions in child custody enforcement cases. Thus, "[a]s a general rule contempt proceedings in child custody and visitation disputes are civil contempts and have a basically remedial focus. They are intended to bring about compliance with the court's prior custody and visitation directives for the benefit of the other party . . .."131

The classic coercive contempt order, based on a finding that the contemnor violated an earlier order of the court, imposes a serial fine or openended jail sentence, which continues until the contemnor satisfies certain conditions set out in the contempt order. These conditions typically require compliance with the terms of the initial court order, thus highlighting the

128. Id. at 91 .

129. Id. at 92. See also Ingebrethsen v. Ingebrethsen, 661 A.2d 403, 405 (Pa. Super. Ct. 1995) (Wieand, J., concurring) (disagreeing with majority's characterization of contempt order as criminal contempt, where mother was ordered to serve a fixed ninety-day jail sentence); Fatemi v. Fatemi, 537 A.2d $840,844-45$ (Pa. Super. Ct. 1988) (characterizing contempt order with sanctions of a $\$ 25,000$ fine and lis pendens order against father's home as civil contempt, even though the trial court had labeled the father's contempt as criminal).

130. 3 RUTKIN, supra note 4 , § 32.11[2][a], at 32-418.

131. 4 LitTLE, supra note $9, \S 25.05[2]$, at 25-149. 
ultimate purpose of the contempt adjudication. Often called a "purge provision," this type of coercive court order enables the contemnor to purge himself or herself of contempt by satisfying the conditions established by the court. As to contempt orders that impose conditional jail sentences, courts often state that the contemnor, by virtue of the purge provision, "hold[s] the keys to his own jail cell." 132 Familiar examples outside the custody area involve the imprisonment of a parent held in contempt for the failure to pay child support, until the parent pays the amount due; or the imprisonment of a trespasser until he or she removes a structure unlawfully placed on the land of another. The essential features of the coercive civil contempt remedy have been summarized in the following manner:

Historically, the primary recourse of the equity court has been personal coercion of the recalcitrant defendant through the use of the power to hold him in civil contempt until he complies. The essence of the civil contempt power is the indefinite cumulative sanction which continues until the defendant has purged himself of contempt by obeying the underlying order. The most familiar of these sanctions are the per diem fine and the continuing imprisonment of the disobedient individual, but other devices are available. ${ }^{133}$

In the custody context, this classic model of the coercive contempt order, including the purge provision, has easy application to cases where one parent unlawfully retains the physical custody of children at the time of the contempt hearing, contrary to the terms of an established custody order. For example, the mother in the case of Mauro v. State ${ }^{134}$ was held in contempt for her failure to comply with a modified custody order requiring her to deliver the children in her physical custody to their father, the newly-named primary custodian. The trial court's contempt order "sentenced [the mother] to 30 days' incarceration ... [and] provided that [she] could 'purge her contempt at any time by immediately releasing the children to the [father]." ${ }^{135}$ Notably, the children were eventually delivered to the father only after the mother was

132. Fischer, supra note $29, \S 314[\mathrm{~b}]$, at 734 .

133. Hirschhorn, supra note 35 , at 1826.

134. 632 So. $2 d 727$ (Fla. Dist. Ct. App. 1994).

135. Id. at 728 (quoting trial court order). In other cases, custody enforcement courts have created purge provisions that substitute a new behavioral requirement for the traditional requirement of compliance by the contemnor with the initial custody order. See, e.g., In re Marriage of Fitzgerald, 690 P.2d 1114, 1115 (Or. Ct. App. 1984) (allowing mother to "purge herself of the contempt by stipulating with [father] to a modification in the visitation schedule"); Curlee v. Howle, 287 S.E.2d 915, 917 (S.C. 1982) ("sentenc[ing] [the father] to one year imprisonment for contempt of court, provided that he be allowed to purge himself of contempt by the payment of [compensatory amounts] to [mother]"). But see Thedieck v. Thedieck, 470 S.E.2d 265, 267 (Ga. Ct. App. 1996) ("To the extent that the trial court's order conditioned [mother's] avoidance of . . incarceration upon payment of the attorney fees award, it was erroneous."). 
arrested with them still in her care. The Mauro court held that the placement of the children with their father, even when accomplished without the voluntary cooperation of the mother, satisfied the purge provision and the remedial goal of the contempt order. The court ruled that the order must therefore be vacated.

At the time of the contempt hearing in Mauro, the mother was in violation of a custody order that apparently required a single act of compliance on her part: transfer of the children to their father. The classic model of the conditional contempt order, combining a fine or jail sentence with a purge provision, was easily applied to this fact pattern. This same type of coercive contempt order does not, however, fit as neatly in another, more common custody enforcement fact pattern.

Many parenting plan orders dealing with the residential aspect of custody require recurring transfers of the children between their parents. Often, one parent petitions for judicial relief because the other parent unlawfully retained physical custody of the children in the past, but by the time the injured parent seeks judicial relief, the children are "where they should be" under the terms of the parenting plan. In these circumstances, the current imposition of a fine or jail sentence cannot, as a practical matter, be used by the court to coerce the compliant behavior that has already occurred. The courts have dealt with this puzzle in various ways, when confronted with requests to hold the formerly noncompliant parent in contempt of court. ${ }^{136}$

Custody courts have sometimes ruled in these circumstances that no coercive civil contempt remedy is available, and have relied exclusively upon their criminal contempt authority. For example, the Pennsylvania trial court in Bruzzi v. Bruzzi $i^{137}$ held the father in contempt for returning his child one week late to the custodial mother following a scheduled period of visitation. The appellate court in Bruzzi characterized the contempt adjudication as necessarily criminal, rather than civil, because no remedial or coercive purpose could be served by the trial court's order. According to the appellate court, "[father] could not be coerced into returning the children; he had already done so." ${ }^{138}$ The Georgia Supreme Court identified the same limitation on coercive judicial authority in the visitation enforcement setting,

136. See 4 RutKIN, supra note $4, \S 47.06[9]$, at 47-94 ("If . . a contemnor is required to perform a continuing series of acts such as having the children available at various intervals or consulting with the other parent prior to making certain decisions ... the framing of an effective order demands flexibility beyond simple imprisonment.").

137. 481 A.2d 648 (Pa. Super. Ct. 1984).

138. Id. at 652 . 
as follows: "With respect to short periods of visitation the most practical means of enforcement is by use of criminal contempt as the visitation time period has usually expired before the court can act."139

Other courts have approached the issue of remedies in this common fact pattern with greater flexibility, by focusing on the possibility of coercing future compliance by the parent who violated residential custody and visitation orders in the past. In formulating a conditional contempt order with this goal in mind, the courts have made adjustments to the "classic purge model" discussed above and illustrated in the Mauro case. ${ }^{140}$

One alternative coercive model is the probationary contempt order, which imposes sanctions for past violations of the initial custody decree, and suspends the fine or jail sentence for so long as the parent remains in compliance. As described by Professor Rutkin, "[a]fter finding that the [initial parenting plan] decree was violated, a court may ... place the parent on probation on the condition that future violations will not occur." 141

In the case of Hudson v. Hudson, ${ }^{142}$ for example, the trial court cited the mother for civil contempt after she failed to comply with both the visitation provision and a property provision in her divorce decree. The trial court imposed a sentence of jail every weekend until she complied with the visitation and property orders, but suspended the sentence "to allow the [mother] to comply with its orders." "143 The contempt order in Hudson also provided that "[i]n the event the Court is not satisfied that the [mother] appreciates the significance of the civil contempt citations, the [c] ourt reserves the right to execute said sentence." ${ }^{144}$ Most likely, the trial court anticipated that no future determination about the mother's "appreciat[ion of] the

139. Fields v. Fields, 240 S.E.2d 58, 60 (Ga. 1977). See also Wilson v. Freeman, 402 So. 2d 1004, 1007 (Ala. Civ. App. 1981) ("There is a serious question as to whether a civil contempt proceeding is an effective remedy for the violation of visitation rights."); Boggs v. Boggs, 692 N.E.2d 674, 678 (Ohio Ct. App. 1997) ("[W]e believe that the court found appellant in criminal contempt for his 'repeated and blatant' exposure of the children to his paramour. Because ... there is no way to purge past violations of said order, we believe that the court did not err in failing to provide a purge mechanism ....").

140. The limitation of remedies to criminal contempt, as in the Bruzzi case, also ignores the possibility of compensatory civil contempt sanctions, which may serve as a satisfactory alternative to criminal penalties for past violations in some cases. See generally infra text accompanying notes 151-72 (discussing compensatory remedies).

141. 3 Rutkin, supra note 4 , § 32.11[2][a], at 32-417. See, e.g., 23 Pa. Cons. Stat. § 4346(a) (2004) (listing imprisonment for up to six months or probation for that period of time, along with other sanctions, in the custody and visitation enforcement statute).

142. 494 So. 2 d 664 (Ala. Civ. App. 1986).

143. Id. at 665-66. Notably, the court in Hudson also imposed a fixed criminal contempt sanction of 120 hours in jail. Id. at 665 .

144. Id. at 667 (quoting the trial court order). 
significance of the civil contempt citations" would ever be made, and that the threat of jail would coerce future compliance. Furthermore, noncompliance in the future would provide the basis for a negative determination about the mother's level of appreciation, resulting in her incarceration under the terms of the contempt order. ${ }^{145}$

The threat of imprisonment under this type of probationary order apparently had the desired coercive effect in the case of In re Marriage of Herrera ${ }^{146}$ In Herrera, after finding that the mother had violated its visitation orders in the past, the trial court imposed a fifteen day jail term, and "[f]ourteen days of the sentence were suspended on the condition that the mother comply with the visitation orders." 147 Thereafter, "the trial court held a review hearing on the contempt citation. It found the mother in compliance with the visitation orders, . . and dismissed the contempt citation." 148

Under probationary contempt orders, illustrated in the Hudson and Herrera cases, the contemnor can avoid the contempt sanction of a fine or imprisonment by satisfying conditions of probation, which generally require the parent's current (post-contempt) compliance with the initial custody decree. This remedial model varies in significant ways from the classic conditional contempt order, which involves the current implementation of a fine or jail sentence until the contemnor acts to remedy past violations of the initial court order. The probationary coercive order is an alternative remedy applicable when the contemnor is guilty of past violations, but has moved into compliance at the time of the contempt hearing, and still has future obligations under the initial custody order. These circumstances characterize many custody and visitation enforcement cases.

Another variation on the classic contempt model, developed for application in these same circumstances, looks to the intention of the contemnor regarding future compliance. Under this "good faith model," the sanction of a fine or imprisonment for past violations of the custody order is

145. In Poston v. Poston, 502 S.E.2d 86 (S.C. 1998), the trial court imposed a fixed jail sentence of 120 days for the mother's past contempt, and suspended the sentence for so long as the mother complied with a no-contact-with-the-children order. The appellate court in Poston noted that, in light of the determinate nature of this sentence, a "new contempt proceeding" would be required before the sentence could be implemented in the future. Id. at 91-92.

146. 772 P.2d 676 (Colo. Ct. App. 1989).

147. $I d$. at 678 .

148. Id. But see In re Marriage of Eilers, 526 N.W.2d 566, 570 (Iowa Ct. App. 1994) (reversing the trial court's "decision to discharge the previously imposed suspended sentences," because "[u]nfortunately, the record suggests the imposition of actual jail time may be the only means by which [mother] will learn how imperative it is she comply with court orders"). 
currently implemented (as in the classic model). The condition imposed on the contemnor that enables him or her to purge the contempt, however, is the demonstration of a good faith intention to comply in the future with the custody order. For example, a Nevada statute dealing with the enforcement of make-up visitation orders provides that "[a] custodial parent imprisoned for contempt ... must be released from jail if the court has reasonable cause to believe that he will comply with the [visitation] order."149 The "future intent" condition here replaces the traditional conduct requirement which cannot, as a practical matter, be imposed in these circumstances. That is, given the nature of the parent's future obligations regarding custody, performance cannot take place while the parent is in jail. ${ }^{150}$

Custody enforcement courts have demonstrated flexibility in shaping contempt orders that are designed to bring parents into compliance with the terms of their post-divorce parenting plans. Both the probationary contempt order and the coercive contempt order with a condition relating to the future intentions of the contemnor are variations on the classic coercive contempt model. They have been designed by the courts to respond to the special features of the underlying judicial orders in custody enforcement cases, which often involve recurring obligations by both parents.

\section{G. Compensatory Civil Contempt Remedies in Child Custody Cases}

Although less common than the coercive function discussed above, custody enforcement courts may also issue civil contempt orders for the purpose of compensating a parent who was injured by the other's past violation of a custody order. Professor James Fischer captured this dual remedial function in describing general civil contempt doctrines, as follows:

149. Nev. Rev. Stat. Ann. § 125C.030(2) (LexisNexis 2004). See also Wilson v. York, 434 So. 2d 260, 261 (Ala. Civ. App. 1983) (affirming contempt order that imposed a fine and jail sentence and suspended the father's visitation rights "until he gave affirmative assurances that such rights would be honored without necessity of regular court hearings for enforcing compliance").

150. This type of "good faith" condition may be employed outside the child custody enforcement context. See Fiss, supra note 35, at 34 (describing a sanction for the violator of a court order not to dump waste into the river, as follows: "[A]s a form of civil contempt, the defendant is jailed until he stops [dumping waste] or until the court is thoroughly satisfied through promises, etc. that he will not [dump waste]."). See generally Michael J. Yaworsky, Annotation, Contempt: State Court's Power to Order Indefinite Coercive Fine or Imprisonment to Exact Promise of Future Compliance With Court's Order-Anticipatory Contempt, 81 A.L.R. 4th 1008 (1990) ("collect[ing] and analyz[ing] the cases deciding whether ... a state court may ... impose an indefinite fine or term of incarceration or threaten to do so as a coercive measure to exact a promise that a person will comply in the future with a particular order or injunction issued by the court"). 
"Civil contempt is identified by its remedial effect. It can compel obedience to a court order for the benefit of the complainant or compensate the complainant for injuries resulting from noncompliance. Thus, either a coercive or a compensatory order may remedy civil contempt." 151 Within this general framework, "[c]ompensatory contempt is a money award for the plaintiff when the defendant has injured the plaintiff by violating an injunction." 152

In the custody area, a number of state statutes expressly authorize this type of compensatory award or fine payable to the injured parent, when the other parent violates the terms of a court-ordered parenting plan. ${ }^{153}$ The courts in custody enforcement cases have relied upon these special family law statutes, or the general civil contempt law of the jurisdiction, in making compensatory awards in child custody and visitation cases. ${ }^{154}$

Scholars in the field of remedies have highlighted an inherent difficulty in awarding money as the remedy for breach of an equitable, coercive order of the court. ${ }^{155}$ In many cases, an injunctive order was entered in the first place because the individual rights protected by the order could not be easily quantified or protected by a monetary award. In the event of a subsequent violation, then, "plaintiffs are faced with the prospect of quantifying the harm that they suffer as a result of the defendant's disobeying the order ... [even though] their injury is by definition difficult if not impossible to measure in money terms." 156

This valuation dilemma has sometimes led to the conclusion that compensatory contempt awards must be disallowed, because they introduce

151. FisCHER, supra note $29, \S 312$, at 723 .

152. Doug Rendleman, Compensatory Contempt: Plaintiff's Remedy When a Defendant Violates an Injunction, 1980 U. ILL. L. ForUm 971, 971. See generally Annotation, Right of Injured Party to Award of Compensatory Damages or Fine in Comtempt Proceedings, 85 A.L.R.3d 895 (1978) (collecting cases outside the field of child custody and visitation). The compensatory fine must be distinguished from the fine payable to the court in criminal contempt cases. See DobBs, supra note 24, § 2.8(3), at 140 ("A compensatory fine is a determinate amount and as such bears one of the marks of a criminal sanction. On the other hand, if it is proportioned to the loss suffered and payable to the party aggrieved, its remedial function seems predominant....").

153. See Mo. Rev. Stat. § 452.400(6)(3) (2000 \& Supp. 2004); Wash. Rev. Code Ann. $\S 26.09 .160$ (2)(b)(ii) (West 2005); W. VA. Code ANN. § 51-2A-9(b) (LexisNexis Supp. 2006). Provisions in other state custody enforcement statutes provide for fines payable to the injured parent as a noncontempt remedy. See Del. Code Ann. tit. 13, § 728(b)(3) (1999); N.J. Stat. Ann. § 2A:34-23.3(d) (West 2000). Additional enforcement devices in custody and visitation statutes, such as provisions for make-up time with children, also have a compensatory purpose. See supra text accompanying notes 71-73.

154. See ElRoD, supra note 51, $§ 15: 7$, at 15-24 n.4 (collecting compensatory contempt cases).

155. See Livingston, supra note 58, at 401-02; Rendleman, supra note 152, at 974.

156. Livingston, supra note 58 , at 402. 
damages into an equitable relief setting. Thus, "[s]ome courts have questioned the remedial or compensatory fine, on the ground that it really awards damages. ..." ${ }^{157}$ Elsewhere, the valuation dilemma has resulted in a limitation on the types of damages available for contempt. Namely, "[i]t is often stated that compensatory contempt is limited to 'actual damages' incurred by the injured party as a result of the contemnor's violation of a court order." 158 Finally, the broadest approach to compensation in civil contempt cases allows reimbursement for actual monetary losses, and also authorizes the courts to undertake the more difficult task of valuing and compensating the injured party's nonmonetary losses. ${ }^{159}$

In the custody area, the complaining parent's losses typically fall into two discrete categories: out of pocket expenses incurred as a result of the other parent's violation of the custody order, and the loss of certain aspects of custody as a result of the same violation. The first category of losses is not likely to raise valuation problems. For example, parents have been reimbursed under the theory of compensatory contempt for expenses relating to the change in travel plans necessitated by the other parent's failure to make children available for scheduled travel, ${ }^{160}$ lost wages representing the parent's

157. DoBBs, supra note $24, \S 2.8(2)$, at 137. See also FISCHER, supra note 29, $\$ 315$, at 738 ("Some jurisdictions do not, however, recognize compensatory damages ....”). See generally FISS, supra note 35, at 54 ("[T] he historical basis of the enforcement technique [of compensatory civil contempt] seems very much in doubt. I am not certain that compensatory-damage civil contempt existed in English equity practice in 1791, nor how it could be squared with the classic maxim that equity acts in personam.") (citations omitted).

158. FisCHER, supra note $29, \S 315$, at 739 . See also Rendleman, supra note 152, at 972 ("Courts measure compensatory contempt by evidence of reimbursable loss.").

159. See Rendleman, supra note 152, at 993 ("Punitive damages for compensatory contempt . . advance the policies of the inadequacy prerequisite... [and] fill the gap between the plaintiff's measurable damages and his legally recognized impairment. Punitive damages ameliorate otherwise uncompensated losses by providing a money substitute for the immeasurable impairment that caused the judge to enjoin initially.").

160. See, e.g., MacIntosh v. MacIntosh, 749 N.E.2d 626 (Ind. Ct. App. 2001). 
time required to litigate the contempt, ${ }^{161}$ attorney fees, ${ }^{162}$ and other out of pocket expenses. ${ }^{163}$

The second category of losses, involving lost time with children, is more difficult to articulate and quantify in individual cases. These losses represent the family-related interests that the initial custody order sought to protect. The Florida court in the case of LaRoche v. Briggs, ${ }^{164}$ for example, recognized and compensated a father's nonmonetary loss when the mother unlawfully retained the physical custody of their daughter for a period of sixty-one days prior to the contempt hearing. The trial court in LaRoche had imposed a fine of one hundred dollars per day payable to the father for each of the sixty-one days. The appellate court reduced this fine by the amount of one hundred dollars for each day on which the initial custody order had authorized visitation by the mother, and otherwise affirmed the contempt order. ${ }^{165}$ Clearly, the appellate court agreed with the trial court that the father, who served as primary residential parent under the initial custody order, had suffered a loss each day without his child, and assigned a value of one hundred dollars to that loss.

The LaRoche court did not, however, detail the nature of the loss so identified and compensated. Presumably, the daily fine in LaRoche reflected the court's attempt to quantify the qualitative experience of spending time with one's children. ${ }^{166}$ In other custody enforcement cases, judges have

161. See, e.g., Meade v. Levett, 671 N.E.2d 1172 (Ind. Ct. App. 1996). But see Ruth v. Ruth, 579 S.E.2d 909, 912 (N.C. Ct. App. 2003) (reversing award for lost wages under a state rule disallowing compensatory awards in custody enforcement cases).

162. See, e.g., Meade, 671 N.E.2d at 1178-79. But see Strickland v. Williams, 218 S.E.2d 8, 10 (Ga. 1975 ) (overruling an award of attorney's fees because such an award was not authorized under the contempt statute in the state family code). See generally, FISCHER, supra note 29, §316, at 740 (noting that some but not all states permit the recovery of attorney fees for prosecuting a civil contempt action, under general civil contempt laws); 4 RUTKIN, supra note 4, § 47.10[1], at 47-109 (attributing the availability of attorney fee awards in post-divorce custody enforcement cases to "the reasoning that, in the absence of statute, the court's continuing subject-matter jurisdiction over the divorce . . . encompasses the authority to award attorney fees").

163. See, e.g., Barton v. Barton, 29 P.3d 13, 18-19 (Utah Ct. App. 2001) (affirming fine payable to father that included costs of his "consultation with a special master"); Zillmer v. Lakins, 544 N.E.2d 550, 551 (Ind. Ct. App. 1989) (affirming fine payable to father that included fee paid to private investigator who located his child).

164. 720 So. 2d 321 (Fla. Dist. Ct. App. 1998).

165. Id. at 322 .

166. See also Luminella v. Marcocci, 814 A.2d 711, 714, 719 (Pa. Super. Ct. 2002) (stating that "[e]ven if the ... fine did not compensate father for litigation expenses, it served to compensate him for mother's violation of his court-mandated rights to custody of his children," in affirming award between never-married parents) (emphasis added)). 
identified "emotional damages"167 and "inconvenience and frustration"168 as additional non-quantitative losses compensable by monetary awards.

There is, however, no uniform rule among the states about the allowability of compensation for these types of nonmonetary losses in custody and visitation cases. The Missouri Court of Appeals in Levis v. Markee, for example, disallowed a fine for civil contempt imposed upon the mother who had "deprived father of two days visitation with [his son]." 169 According to the Levis court, "an outright fine, unrelated to actual damages, is not appropriate for civil contempt because it is not designed to cure but is intended to punish." ${ }^{170}$ Thus, the court failed to recognize the father's lost time with his son as a compensable loss. The lack of uniformity on this issue in child custody enforcement cases, illustrated by a comparison of the LaRoche and Levis cases, reflects the variation in general state contempt doctrines regarding compensation for nonmonetary losses in civil contempt proceedings. ${ }^{171}$

In the custody enforcement context, where the contemnor who violated obligations in the past still owes continuing obligations in the future under the terms of an initial custody order, compensatory payments for past violations may be an inadequate remedy. In the LaRoche case, for example, the Florida court combined the fixed compensatory fine of $\$ 100$ per day for the mother's past violations, described above, with a coercive contempt order that addressed the need for her future compliance. Specifically, the LaRoche court imposed a conditional fine of $\$ 100$ for each day following the contempt hearing that the mother retained custody of her child contrary to the residential custody schedule established in the initial custody order. ${ }^{172}$

Thus, the courts have been flexible in formulating civil contempt remedies in custody and visitation enforcement cases. This flexibility is demonstrated by the combination of compensatory and coercive contempt sanctions in the LaRoche case, and the judicial variations on the classic "purge model" of the coercive contempt remedy discussed in the last Section. These remedies reflect the special nature of enforceable parenting plan orders. Many custody and visitation orders regulate the conduct of parents regarding

167. Habie v. Habie, 654 So. 2d 1293, 1294-95 (Fla. Dist. Ct. App. 1995).

168. Meade v. Levett, 671 N.E.2d 1172, 1181 (Ind. Ct. App. 1996).

169. Levis v. Markee, 771 S.W.2d 928, 932 (Mo. Ct. App. 1989). See also Wilson v. Sullivan, 922 S.W.2d 835, 839 (Mo. Ct. App. 1996) (reversing fine payable by mother to father for past visitation interference because "there was no evidence the fine was ... related to actual damages suffered by father"). 170. Levis, 771 S.W.2d at 932.

171. See supra text accompanying notes 155-59.

172. See Laroche v. Briggs, 720 So. 2d 321, 322 (Fla. Dist. Ct. App. 1998). 
essential family matters over a period of many years, in order to protect parent-child relationships in the nonintact family. The complex nature of these orders and the importance of the interests they protect create the need for flexible remedies when parents violate the terms of post-divorce custody and visitation orders.

\section{SUMMARY}

Family law statutes in every state govern the child-related issues that arise at the time of divorce. As a general rule, these statutes require the divorce courts to enter coercive orders that will govern the residential and decisionmaking aspects of post-divorce parent-child relationships. The laws in many states also set out the remedies, including civil and criminal contempt, available to enforce court-ordered parenting plans in the event of parental noncompliance. This area of statutory regulation, which touches the lives of millions of families every year, is in many ways sui generis. At the same time, the coercive nature of the court-ordered terms of post-divorce parenting plans, and the availability of enforcement by civil or criminal contempt remedies, place custody and visitation orders in a larger doctrinal context. This Article analyzed child custody and visitation laws against this backdrop of the law of injunctions and the law of contempt.

The family law system assigns priority to the maintenance of established relationships between children and both of their parents following the parents' divorce. This priority leads to certain variations from the general model of injunctive remedies in many child custody cases. For example, divorce courts formulate the initial coercive parenting orders, which become immediately enforceable by contempt remedies upon violation by one parent, without making any determination of prior wrongdoing by either parent. Furthermore, the courts routinely enter coercive orders addressing the residential and decisionmaking aspects of post-divorce parenting, even though the anticipated period of judicial regulation is lengthy (until the children's ages of majority), and despite evidence of likely compliance problems. Finally, in the event of parental noncompliance, judicial enforcement via contempt remedies may involve the entry of orders that vary significantly from the classic contempt model, especially when the contempt remedy is civil rather than criminal in nature.

Parenting plan orders typically set out specific responsibilities for both parents, to be performed over a period of years until the children become adults. The nature of these orders, involving recurring patterns of family behavior, and the importance of the interests that they seek to protect have 
shaped many of the family law doctrines discussed in this Article. These doctrines have molded the general law of injunctions to fit a unique legal context, the creation and enforcement of post-divorce custody orders. 